\title{
Karabük Ovacık Çukur Camisi Yapı Malzemelerinin Arkeometrik
} Analizleri

\section{Archaeometric Analyses of the Building Materials for the Karabük Ovacik Çukur Mosque}

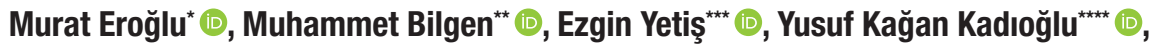 Kıymet Deniz}

\section{Öz}

Bu çalışmada, Karabük Ovacık Çukur Camisi yapı malzemelerinin korunmasına yönelik özelliklerinin analitik yöntemlerle tespiti amaçlanmıştır. Karabük Ovacık Çukur Camisi, Karabük'ün Ovacık ilçesine bağlı Çukur köyünde bulunmaktadır. Köy, ilçe merkezine 12 km mesafededir. Ovacık ilçesi de Karabük iline 48 km mesafededir. Ahşap çatılı olan yapı yalnızca harim kısmından oluşmaktadır. Mimari özelliklerinden dolayı 19. yüzyıl sonu, 20. yüzyıl başlarına tarihlendirilen caminin taş, harç, sıva ve boya örnekleri incelenmiştir. Örneklenen yapı malzemeleri ve hammadde örneklerinin fiziksel, kimyasal ve petrografik analizlerle özellikleri belirlenmiştir. Bu kapsamda silikatlı agrega/bağlayıcı analizi, granülometrik elek analizi-agregada tane boyutu dağılımı, X-Işını Floresans (XRF) analizi, Konfikal Raman Spektroskopisi (KRS) analizi, Fourier Dönüşümlü Kızılötesi Spektroskopisi (FT-IR) analizi ve petrografik incelemeler yapılmıştır. Çalışma kapsamında, Karabük Ovacık Çukur Camisi'ne ait malzeme numuneleri fotoğraflanarak belgelenmiş ve laboratuvar çalışmaları için kodlanmıştır. Çalışmanın sonucunda harç ve sıvaların agrega-bağlayıcı özellikleri belirlenmiş, bazı örneklerin çimento bağlayıcısı içerdiği, boyalarda ise çeşitli mineral kaynaklı pigmentler ile birlikte organik katkıların kullanıldığı tespit edilmiştir.

\section{Anahtar Kelimeler}

Çukur Camisi, Yapı malzemeleri, Arkeometri, Pigment, Bağlayıcı, Petrografi, XRF, KRS, FT-IR

\section{Abstract}

This study aims to determine the conservation status of Karabük Ovacık Çukur Mosque building materials using analytical methods. Çukur Mosque is connected to the Ovacık district of Karabük and is $12 \mathrm{~km}$ away from the district center. The distance between Karabük and Ovacık is $48 \mathrm{~km}$. Originally, the wooden roofed building consisted of a harim. Stone, mortar, rendering, and paint samples of the mosque were examined due to their architectural properties, dated to the end of the

* Sorumlu Yazar: Murat Eroğlu (Dr. Öğr. Üyesi), Kastamonu Üniversitesi, Fen-Edebiyat Fakültesi, Arkeoloji Bölümü, Kastamonu, Türkiye. E-posta: meroglu@kastamonu.edu.tr, ORCID: 0000-0001-8807-3906

** Muhammet Bilgen (Dr. Öğr. Üyesi), Kastamonu Üniversitesi, Güzel Sanatlar ve Tasarım Fakültesi, Geleneksel Türk Sanatları Bölümü, Kastamonu, Türkiye. E-posta: mbilgen99@gmail.com, ORCID: 0000-0002-9132-3950

*** Ezgin Yetiş (Dr. Öğr. Üyesi), Kastamonu Üniversitesi, Güzel Sanatlar ve Tasarım Fakültesi, Sanat Eserleri Konservasyonu ve Restorasyon Bölümü, Kastamonu, Türkiye. E-posta: ezginyetis@hotmail.com, ORCID: 0000-0003-3375-7432

**** Yusuf Kağan Kadığlu (Prof. Dr.), Ankara Üniversitesi, Mühendislik Fakültesi, Jeoloji Mühendisliği Bölümü, Ankara, Türkiye. E-posta: kadi@eng.ankara.edu.tr, ORCID: 0000-0002-7894-2220

****** Kıymet Deniz (Dr. Öğr. Üyesi), Ankara Üniversitesi, Mühendislik Fakültesi, Jeoloji Mühendisliği Bölümü, Ankara, Türkiye. E-posta: kdeniz@eng.ankara.edu.tr, ORCID: 0000-0003-3208-1354

Atıf: Eroglu, Murat, Bilgen, Muhammet, Yetis, Ezgin, Kadioglu, Yusuf Kagan ve Deniz, Kiymet. “Karabük Ovacık Çukur Camisi Yapı Malzemelerinin Arkeometrik Analizleri." Art-Sanat, 16(2021): 151-179.

https://doi.org/10.26650/artsanat.2021.16.0006 
$19^{\text {th }}$ and beginning of the $20^{\text {th }}$ century. Analytical methods were used to determine the physical, chemical, and petrographic properties of building materials, including raw material samples. The following techniques were used for performing the analysis: Silicate aggregate/binder analysis, granulometric sieve analysis-particle size distribution, X-Ray Fluorescence analysis, Confocal Raman Spectroscopy analysis, Fourier Transform Infrared Spectroscopy analysis, and petrographic examinations. Material samples were photographed, documented, and coded for laboratory studies within the scope of the study. The results showed the identification of aggregatebinder properties in mortars and renderings and cement in some samples. Conversely, various pigments of mineral origin and organic properties were identified in paints.

Keywords

Çukur Mosque, Historical Construction Materials, Archeometry, Pigment, Binders, Petrography, XRF, CRS, FT-IR

\section{Extended Summary}

The Çukur Mosque is connected to the Ovacık district of Karabük and is $12 \mathrm{~km}$ away from the district center. The distance between Karabük and Ovac1k is $48 \mathrm{~km}$. No information or written record about the date of construction of the mosque and its owner are found. Based on reports in the archives of Kastamonu Regional Directorate of Foundations, the building was dated between the end of the $19^{\text {th }}$ and beginning of the $20^{\text {th }}$ century. The structure is divided into two sections: the harim (inner side of the mosque) section and an additional section, which was built later adjacent to the north direction. The façades of the harim were built with face stone in the corners and rough-hewn stone and the masonry of rubble stone in the body walls. Wooden girders were used in the masonry at certain intervals on the façades. The entrance to the building, which was originally a single venue, was from the north, although it is now on the western side of the additional section, which was built adjacent to the building in the north direction. However, the portico (narthex) and additional section consisting of rooms were designed as a two-story structure. During the 2018-2019 restoration, it was left as a two-story, but the section with the rooms was reduced to a single floor (Kastamonu Regional Directorate of Foundations Archive). A room can be found to the east of the entrance area. The second floor (women's balcony/ makhpil) is accessed via wooden stairs to the south of the entrance. The entrance to the harim from the extension section is constructed from the north via a wooden double-wing door set inside a stone, flattened round arch. To the west of the door, on the final rendering, the inscription "bismillahirahmanirahim" is written in black, and again in black rulers with taliq calligraphy. The joisting of the ceiling is in the bottom-covered ceiling technique. The joints of the girders are covered with profiled laths, which energize the surface as well. At the center of the ceiling, an octagonal core is painted in a geometrical arrangement in the tones of yellow, blue, red, and green. The wooden Islamic pulpit of the mosque, made using a hammering technique, is located in the western corner of the south wall, adjacent to the west wall, and is not original. The mihrab (Islamic altar) made with plaster work as a relief technique is decorated with plant motifs. In addition to wood and plaster work, kalem isi (Ottoman decorative wall painting technique) made with print, template, and brush techniques 
are seen on the inner surfaces of the four walls of the mosque. A total of 22 mortars, renderings, and paint samples were examined within the scope of the archaeometric analysis performed in the Çukur Mosque. Samples of the structural materials (stone, mortar, rendering, and paint) were also examined.

Mineralogical and petrographic examinations were performed from open-top thin sections using a polarizing microscope. The following techniques were used for the analysis: Silicate aggregate/binder analysis, granulometric sieve analysis (particle size distribution), X-Ray Fluorescence Spectrometry analysis, Confocal Raman Spectroscopy analysis, and Fourier Transform Infrared Spectroscopy. The building is a masonry wall with a rubble foundation. While face stones are used in the corners, edges of the window, and door jambs on the wall, they are generally built with rough-hewn stone, and samples are taken from both the types of stone. On the interior of the building, sampling could be made from the places where rendering was removed from the west, south, and north walls, but on the east wall, the sampling could not be made because it is a well conservated wall. However, it is thought that the eastern and other walls contain similar features when examined visually. The smooth face stone and rough-hewn stone samples taken from the building were both identified as metasandstone similar to each other. Two types of renderings were found on the west wall. The first is the rendering at the back of the pulpit and it consists of two layers. The lower layer of this rendering $(\mathrm{S} 1 \mathrm{~b})$ is a rough and clay + straw + tow-added rendering on the stone wall, similar to rendering consisting of clay + lime used in the rubble filling. Conversely, the upper layer (S1a) is a final rendering with lime + tow. The rendering with clay + straw + tow must have been removed over time, and a new rendering was made. Thus, the original rendering behind the pulpit was preserved. The late period rendering is cement-containing rendering found on the south, north, and west walls. However, the sampling could not be constructed without causing damage to the original work on the east wall, which was in a good condition. The cement-containing rendering on the west, south, and north walls have similar aggregate-binding ratios, aggregate sizes, and chemical contents. This result has been determined both petrographically and chemically. The aggregate ratios and sizes of the mortar (H1) and rendering $(\mathrm{S} 1 \mathrm{~b})$ formed with clay + lime adobe mortar are very similar. However, unlike the other, the S1b sample contains rendering, broken bricks, and tow. The paint samples were taken from the back of the mihrab (islamic altar) and the pulpit (original periods), showing that pigments of natural mineral origin were generally used but artificial chrome yellow was preferred as well. Furthermore, it was concluded that binders of organic origin (polysaccharide, protein, oil, and resin) are used in the paints, which should be thoroughly examined in future research. 


\section{Giriş}

Yapı malzemelerinin korunmasına yönelik olarak özelliklerinin analitik yöntemlerle tespiti amaçlanan Çukur Köyü Camisi, Karabük'ün Ovacık ilçesine bağlı Çukur köyünde bulunmaktadır. Köy, ilçe merkezine $12 \mathrm{~km}$ mesafededir. Ovacık ilçesi de Karabük iline 48 km mesafededir.

Çukur Köyü’nün orta bölümünde düz bir arazi üzerinde bulunan ve köy tüzel kişiliğine ait olan cami (G. 1) Karabük ili, Ovacık ilçesi, Çukur Köyü, 152 ada, 195 parselde kayıtlıdır. Cami, Ankara Kültür ve Tabiat Varlıklarını Koruma Bölge Kurulu'nun 07.3.2003 tarih ve 8442 sayılı kararı ile korunmas1 gerekli kültür varlı̆ğ1 olarak tescil edilmiştir' ${ }^{1}$ Yapım tarihi ve yaptıranı ile ilgili herhangi bir bilgi ya da yazılı kayıt mevcut değildir. Kastamonu Vakıflar Bölge Müdürlüğü’nün arşivlerinde yer alan yapı ile ilgili raporlarda "duvar kalınlığının yaklaşık bir metre olması, geniş saçak sistemine sahip olması" gibi özelliklerinden dolay1 19. yüzyıl sonu, 20. yüzyıl başına tarihlendirilebileceği belirtilmektedir.

Yap1, harim bölümü ile kuzey yönde yapıya bitişik olarak sonradan inşa edilen ek bölüm olmak üzere iki bölümden oluşur. Harim duvarları köşelerde kesme, beden duvarlarında kaba yonu ve moloz taştan yığma tekniğinde yapılmıştır. Cephelerde duvar örgüsünde belirli aralıklarla ahşap hatıllar kullanılmıştır.

Yapıya giriş kuzeyden sağlanmakta iken, günümüzde kuzey yönde yapıya bitişik olarak sonradan inşa edilen ek bölümün batı yönünden sağlanmaktadır. Son cemaat yeri ve odalardan oluşan ek bölüm iki katlı olarak tasarlanmışken 2018-2019 restorasyonunda son cemaat yeri iki katlı olarak bırakılmış fakat odaların olduğu bölüm tek kata düşürülmüsstür ${ }^{2}$. Giriş mekânının doğusunda bir oda yer almaktadır. İkinci kata (kadınlar mahfeline), girişin güneyindeki ahşap merdivenler aracıllı̆̆ ile çıkılmaktadır.

Eklenti bölümünden harime giriş; kuzeyden, taştan yapılma ve basık yuvarlak kemer içine yerleştirilen ahşap, çift kanatlı kapı ile sağlanmaktadır. Kapının batısında sıva üstüne siyah renkte ve yine siyah cetveller içerisine talik hat ile yazılmış 'bismillâhirrahmânirrahîm' yazısı yer almaktadır (G. 1).

Harim yaklaşı olarak 11.30x8.75 m boyutlarında dikdörtgen şeklinde ve duvarlar 0.85-0.87 m kalınlığındadır. Yapı, güney cephesinde üstte iki; batı cephesinde altta bir ve üstte iki; doğu cephesinde altta bir olmak üzere altı tane pencere ile aydınlatılmaktadır. Ahşap kasalı pencereler yörede 'muşabak' olarak adlandırılan, çaprazlamasına yerleştirilen ahşap çıtaların oluşturduğu şebeke ile kapatılmıştır.

1 Kastamonu Vakıflar Bölge Müdürlüğü Arşivi.

2 Kastamonu Vakıflar Bölge Müdürlüğü Arşivi. 

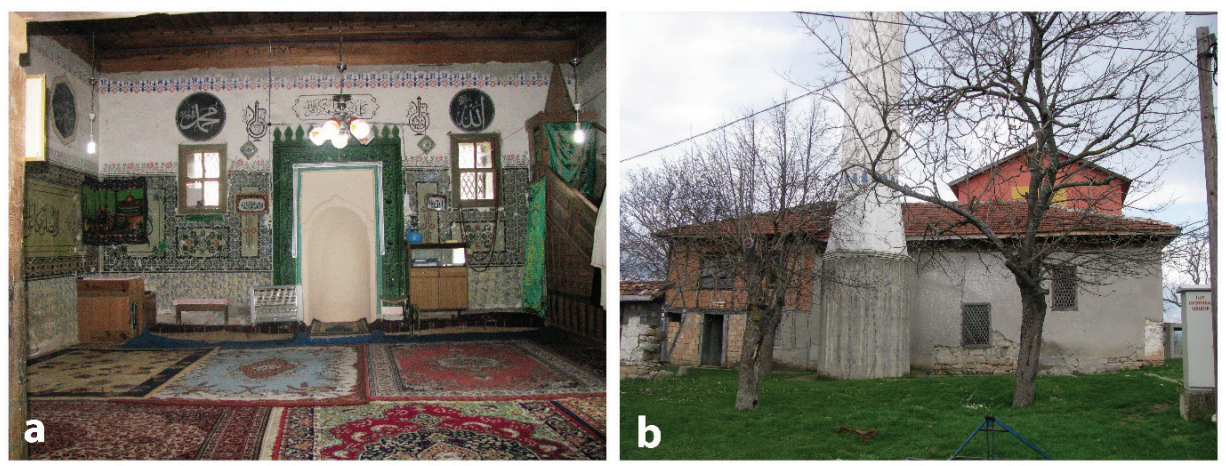

G. 1: Karabük Ovacık Çukur Camisi. a- harim mihrap duvarından bir görünüm, b- dıştan batı duvarı ve minarenin görünümü (Fehmeddin Demirci, Kastamonu Vakıflar Bölge Müdürlüğü Arşivi, 2015)

Yapıda harime giriş kapısı dışında, taban döşemelerinde ve örtü elemanı olan tavanda, minberde ve kadınlar mahfilinde de ahşap işçiliği ile karşılaşıllır. Kuzeydeki, ikisi duvara bağl1, ikisi serbest olmak üzere dört tane kare kesitli dikme üzerine oturan 7.00x 2.50m boyutlarındaki kadınlar mahfili güneyde ahşap korkuluklarla sınırlandırılmıştır.

Tavan; kirişlemesi alttan kaplamalı tavan tekniğindedir. Kirişlerin birleşme yerleri profilli çıtalarla kapatılmış, bu aynı zamanda yüzeyi hareketlendirmiştir. Tavanın ortasında içi geometrik düzenlemeli sarı, mavi, kırmızı, yeşil ve tonlarında boyanmış sekizgen göbek yer alır. Bu göbek üzerinde, okunabildiği kadarı ile metal çivilerle ve Latin harfleri ile "Oflu Usta Kazım, 1958, 1x5", Arap harfleri ile "كازيم , (Kazım, 1272) ibareleri bulunmaktadır.

Caminin çakma tekniğinde yapılan ahşap minberi güney duvarının batı köşesinde, batı duvarına bitişik olarak konumlandırılmıştır ve özgün değildir. Külahlı taht bölümüne, taç (tepelik), aynalık, kare kesitli kapı yan söveleri ve kapalı bir korkuluğa sahip olan minber yalnızca yan aynalık bölümünde çıtakâri tekniğinde yapılmış geometrik kompozisyonlar içeren sade bir düzenlemeye sahiptir.

Alçı döküm tekniği ile yapılmış mihrap kabartma bitkisel motiflerle süslüdür. Ahşap ve alçı işçiliğinin yanı sıra caminin dört duvarının iç yüzeylerinde baskı, şablon ve firça teknikleri ile yapılmış kalem işleri görülür³.

3 Lütfiye Göktaş Kaya ve Şeref Kaya, "Çukur Village Mosque With Its Architectural Properties And Hand Drawn Ornaments”, Uluslararası Sosyal Araştırmalar Dergisi 49(10), (2017), 201-205. 


\section{Örnek Alma ve Belgeleme}

Çukur Camisi'nden incelenmek üzere malzeme analizleri kapsamında, toplam 22 adet harç, sıva ve boya örneği alınmıştır. Camiye ait yapısal malzeme (taş, harç, sıva, boya) örnekleri görsel olarak değerlendirilip belgelenerek gruplandırılmıştır (G. 2). Taş örnekleri iç cephe örgüsünden; harç örnekleri iç cephelerde derz ve moloz dolgulardan ve mihraptan; sıva örnekleri ise iç cephelerdeki taş duvar ve mihrap üzerlerinden katmanlar hâlinde alınmıştır (G. 3 ve G. 4).

Çukur Camisi'ne ait yapı malzemelerinin belgelenmesini ve araştırılmasını amaçlayan çalışmalar; "Ankara Üniversitesi Yer Bilimleri Uygulama ve Araştırma Merkezi (YEBİM)" ve "Kastamonu Üniversitesi Merkezi Araştırma Laboratuvarı Uygulama ve Araştırma Merkezi (MERLAB)"nde bulunan cihazlar kullanılarak yapılmıştır.

Güney, kuzey ve doğu duvarlarında sıvalar ve üzerindeki kalem işleri korunmuş olduğu ve buralarda tahribata neden olmamak için duvar örgüsünden örnek alınamamıştır. Batı duvarı minber arkasında orijinal sıva görülmektedir. Bu sıva yer yer dökülmüş̧ür. Bu nedenle buradan taş temel içerisinden sadece çamurdan oluşan moloz dolgu harcı örneği alınmıştır. Duvarın üzerinde kaba saman katkılı kerpiç çamuru ile yapılmış sıva ve onun üzerinde bir sıva tabakası ile mihrap harcı da örneklenmiştir.

Örnekler arazi çalışması ve sonrasında fotoğraflanarak belgelenmiş, gruplandırılarak kodlanmıştır. Kodlamada KÇC (=Karabük Çukur Camisi), T1 kodu 1 nolu taş örneğini ifade etmektedir. Örneklemelerde duvar yüzeyinde en alt tabakadan itibaren sıvalar isimlendirilmiştir. S1 a üst ve S1b alt sıva tabakasını göstermek üzere kodlanmıştır. $\mathbf{H}$ kodu harç, $\mathbf{P}$ kodu ise pigment örneklerini ifade etmektedir. Pigmentlerdeki (P) P1a ve P1b gibi küçük harfler aynı boya tabakasındaki farklı renkleri belirtmektedir ${ }^{4}$ (Tablo 1).

Tablo 1: Çukur Camisi taş, harç, sıva ve boya örnekleri (Eroğlu, Yetiş, 2021)

\begin{tabular}{|l|l|c|}
\hline Örnekler & Açıklamalar & Malzeme Türüi \\
\hline H1 & $\begin{array}{l}\text { Batı duvarı ile güney duvarı köşesi, minber arkasından taş duvar derz } \\
\text { harcı }\end{array}$ & Harç \\
\hline H2 & Mihrap çerçevesi & Harç \\
\hline S1a & Batı duvarı, minber arkasından üst kat ince sıva & Siva \\
\hline S1b & Batı duvarı, minber arkasından alt kat kaba sıva & Siva \\
\hline S2 & Güney duvarı mihrabın batısından pencere altından & Siva \\
\hline S3a & Mihrap içinden üst kat sıva & Siva \\
\hline S3b & Mihrap içinden alt kat sıva & Siva \\
\hline S4 & Batı duvarından & Siva \\
\hline S5 & Ek bölüm kuzey duvarından & Siva \\
\hline
\end{tabular}

4 Makale içerisinde özellikle metin kısımlarında sadeleştirme amaçlı "KÇC" kodu kullanılmamıştır. 


\begin{tabular}{|l|l|c|}
\hline T1 & Mihraptan & Taş \\
\hline T2 & Köşe/söveden & Taş \\
\hline P1a & Güney duvarı mihrabın batısından pencere altından (koyu mavi) \\
\hline P1b & Güney duvarı mihrabın batısından pencere altından (siyah) & Pigment \\
\hline P1c & Güney duvarı mihrabın batısından pencere altından (açık mavi) & Pigment \\
\hline P1d & Güney duvarı mihrabın batısından pencere altından (kırmızı) & Pigment \\
\hline P2a & Mihrap içinden üst kat ince sıva üzeri pigment (yeşil) & Pigment \\
\hline P2b & Mihrap içinden üst kat ince sıva üzeri pigment (sarımsı kahve) \\
\hline P3a & Batı duvarı sıva üzeri pigment (sarı) & Pigment \\
\hline P3b & Batı duvarı sıva üzeri pigment (yeşil) & Pigment \\
\hline P3c & Batı duvarı sıva üzeri pigment (kırmızı) & Pigment \\
\hline P4 & Ek bölüm kuzey duvarı sıva üzeri pigment (yeşil) & Pigment \\
\hline P5a & Batı duvarı, minber arkasından üst kat ince sıva üzeri pigment (siyah) & Pigment \\
\hline P5b & Batı duvarı, minber arkasından üst kat ince sıva üzeri pigment (kırmızı) & Pigment \\
\hline & & \\
\hline
\end{tabular}

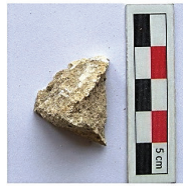

KÇC-T1

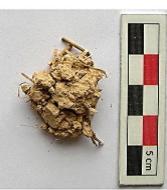

KÇC-S1b

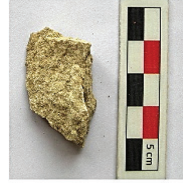

KÇC-T2

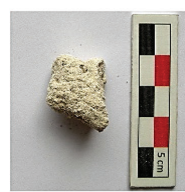

KÇC-S2

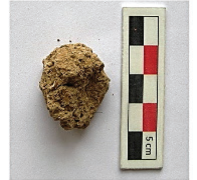

KÇC-H1

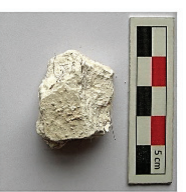

KÇC-S3ab

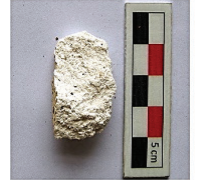

KÇC-H2

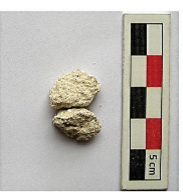

KÇC-S4

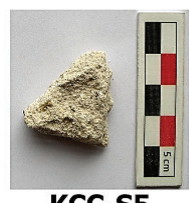

KÇC-S5

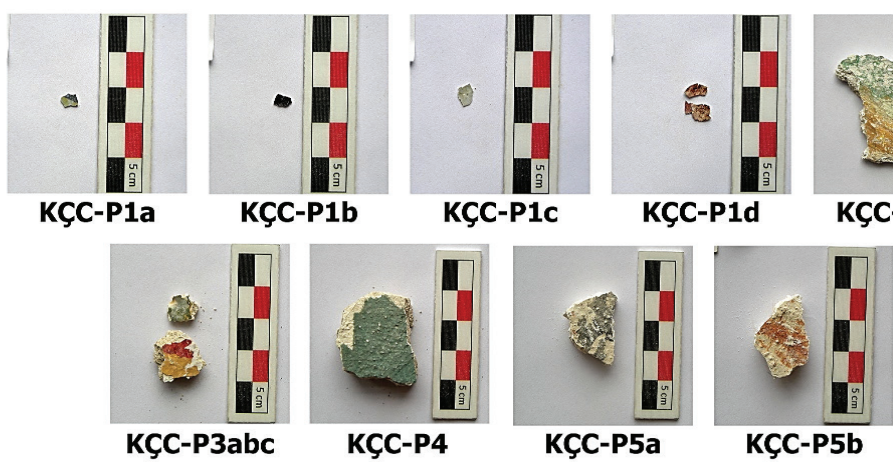

G. 2: Karabük Çukur Camisi'nden alınan yapı malzemesi örneklerinin makro fotoğrafları (Eroğlu, Yetiş, 2020) 


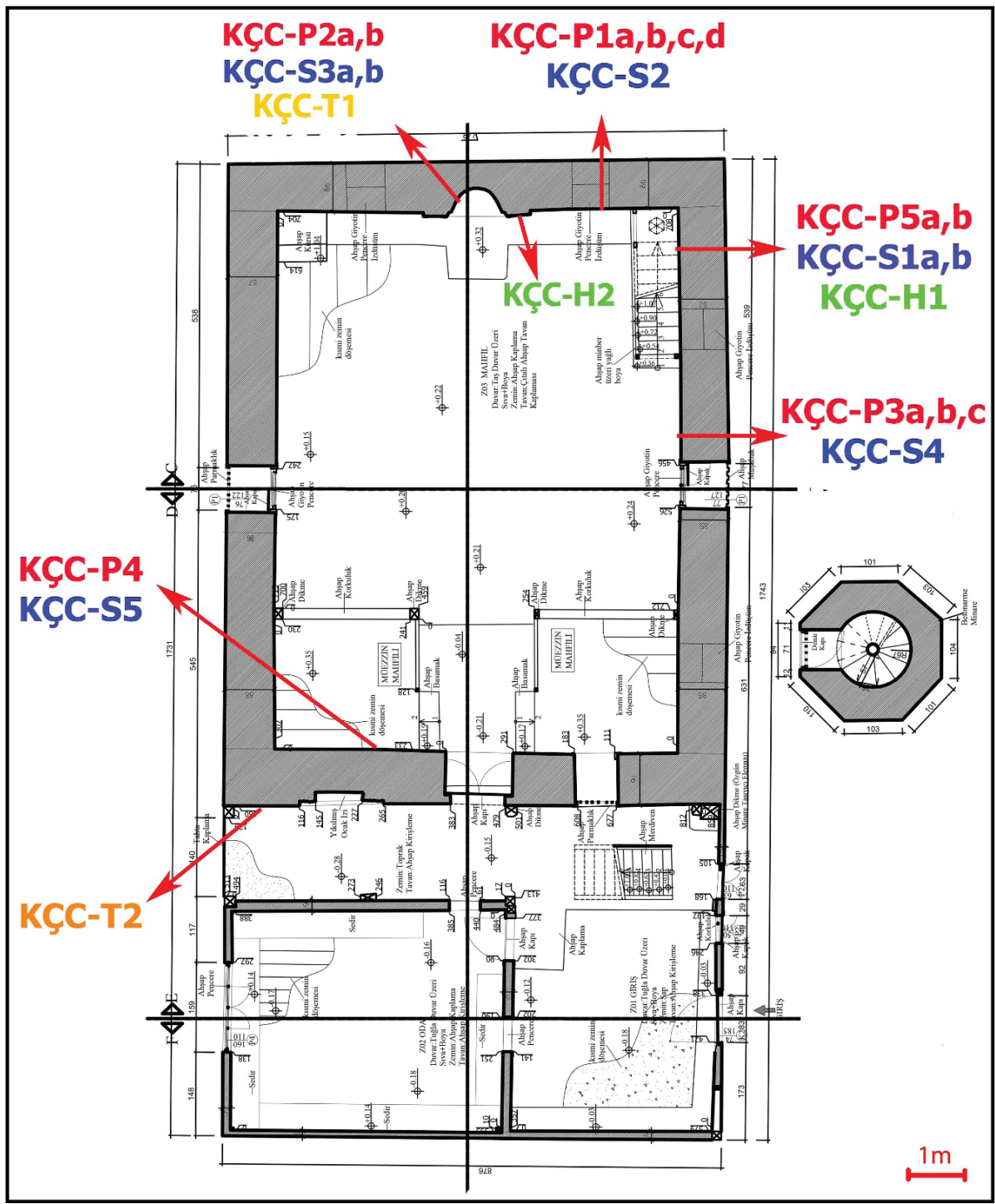

G. 3: Karabük Çukur Camisi örnek alım yerlerini gösteren zemin kat planı

(Plan: Avan Mimarlık Restorasyon, 2016, Düzenleme: M, Eroğlu, E. Yetiş, 2021) 


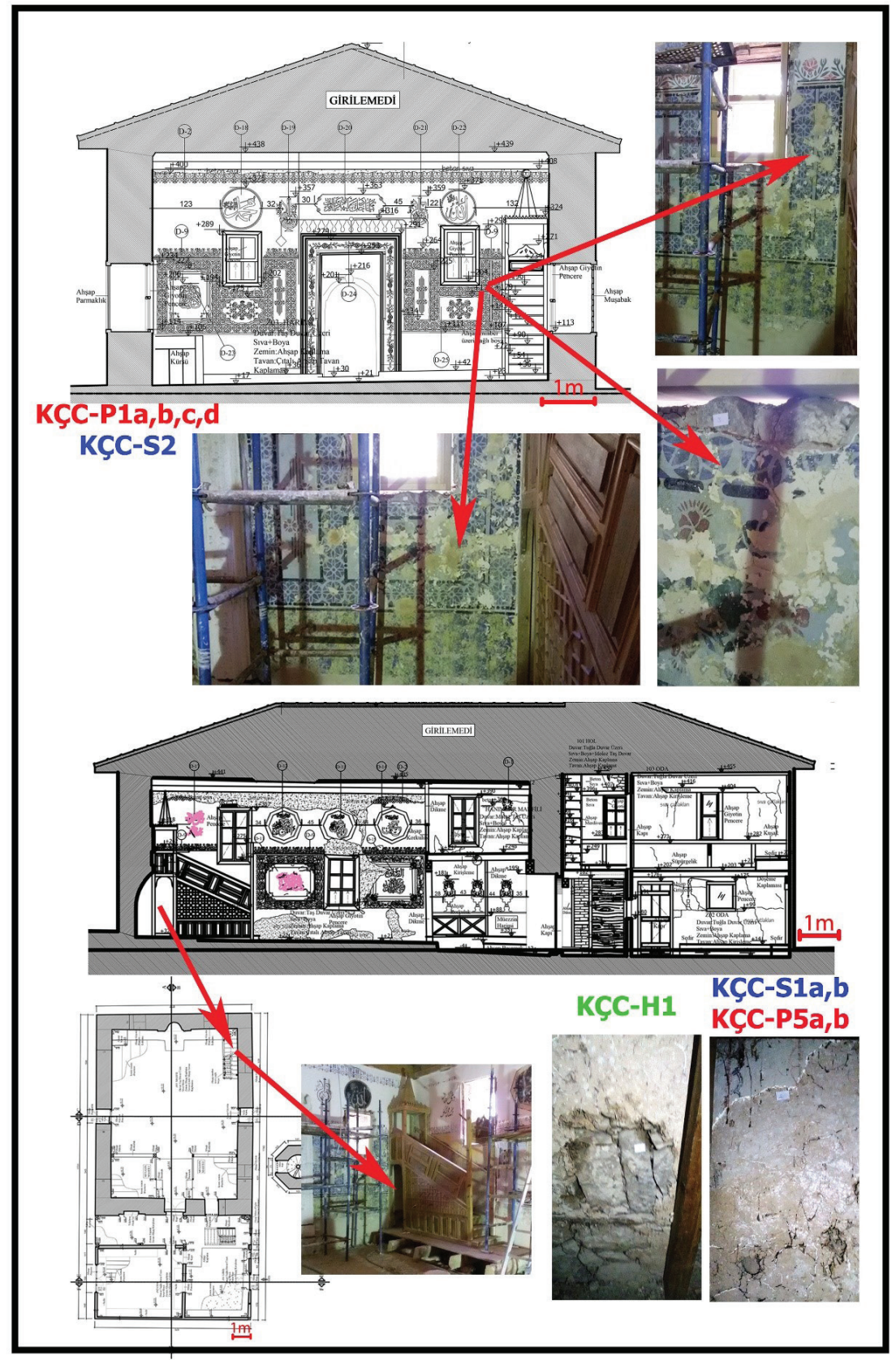

G. 4: Karabük Çukur Camisi’nde örnek alım yerlerini gösteren plan (yukarıdan aşağıya: C-C kesit, B-B kesit ve zemin kat planı) ve fotoğraflar (Plan: Avan Mimarlık

Restorasyon, 2016, Düzenleme: M, Eroğlu, E. Yetiş, 2021) 


\begin{abstract}
Analizler
Çukur Köyü Camisi’nin taş, harç, sıva ve boya gibi yapı malzemelerinin fiziksel, kimyasal ve petrografik özellikleri arkeometrik analizlerle belirlenmiştir. Bu kapsamda taş, harç ve sıva örnekleri üzerinde fiziksel deneyler yapılmış, örneklerde içyapının karakterize edilmesi amacıyla da X-Işını Floresans (XRF) analizleri ile petrografik incelemeler gerçekleştirilmiştir. Boya örneklerine ise; Konfikal Raman Spektroskopisi (KRS) ve Fourier Dönüşümlü Kızılötesi Spektroskopisi (FT-IR) analizleri uygulanmıştır.

Mineralojik ve petrografik incelemeler, ilgili numuneler ile ince kesit hazırlanarak polarizan mikroskop altında gerçekleştirilmiştir. Harç ve sıva örneklerin agrega/bağlayıcı oranları petrografik olarak ve asit kaybı deneyi ile belirlenmiş, asit etkisinde çözünmeden kalan silikatlı agregalar üzerinde de tane dağılım oranlarını tespit etmek için elek analizi (granülometri ölçümleri) yapılmıştır. Örneklerin içyapı özellikleri ve nitelikleri ise XRF, KRS ve FT-IR yöntemleriyle karakterize edilmiştir.

Agrega / Bağlayıcı kompozisyonu, harç ve sıvaların içeriğinde bulunan agrega ve bağlayıcı oranlarını belirlemek için asit kaybı deneyi uygulanırken, tespit edilen agregaların boyutlarını ve tane dağılım oranlarını belirlemek için de elek analizi (granülometri) kullanılmaktadır. Elek analizinde (agregaların tane boyutu dağılımı), asit kaybı sonrası reaksiyona girmeyen agregalar önce $105^{\circ} \mathrm{C}$ 'de sabit tartıma kadar kurutulduktan sonra desikatörde soğutulmuş (G. 5), sonra sirasiyla 1000, 500, 250, 125 ve $63 \mu \mathrm{m}$ gözlü eleklerden geçirilerek tane boyutlarına ayrılmışlardır5.
\end{abstract}

5 Nimet Alkan, Ergün Çağıran, Hazal Özlem Ersan ve Mustafa Eruş. Restorasyon ve Konservasyon Laboratuvarları (İstanbul: İstanbul Büyükşehir Belediyesi İmar ve Şehircilik Daire Başkanlığı Koruma Uygulama ve Denetim Müdürlüğü (KUDEB) Restorasyon ve Konservasyon Laboratuvarları Yayınları, 2011), 58. 


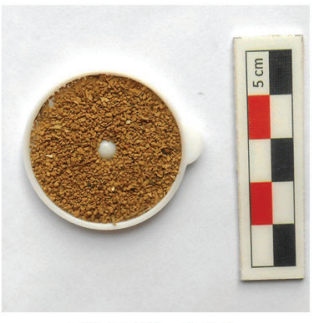

KÇC-H1

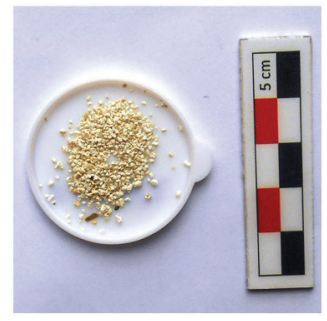

KÇC-H2

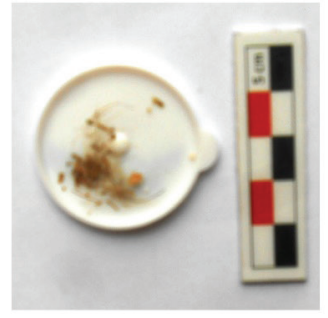

KÇC-S1a

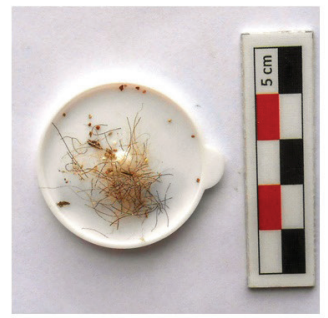

KÇC-S3b

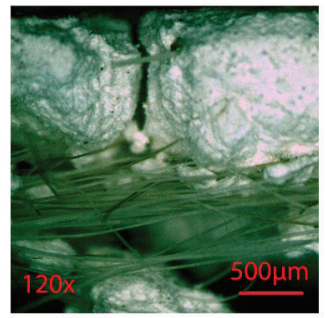

KÇC-S1a

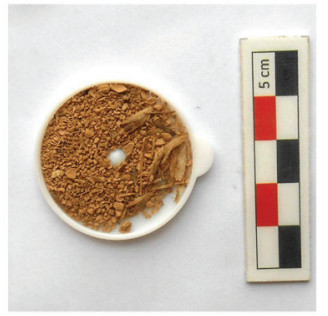

KÇC-S1b

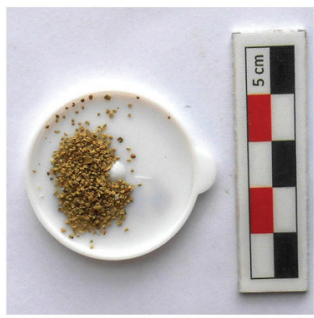

KÇC-S4

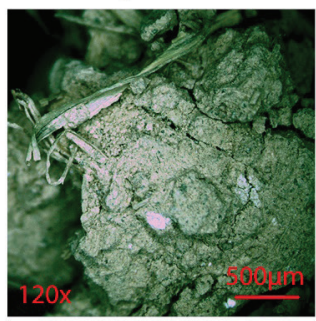

KÇC-S1b

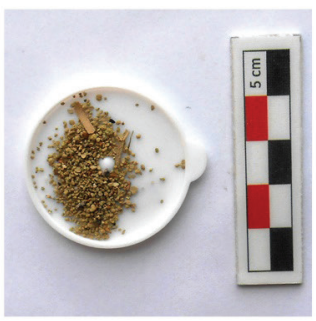

KÇC-S2

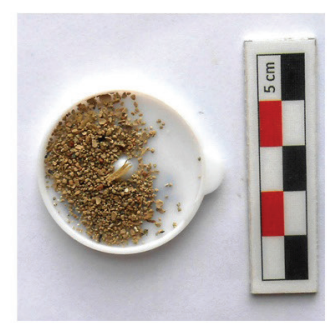

KÇC-S5

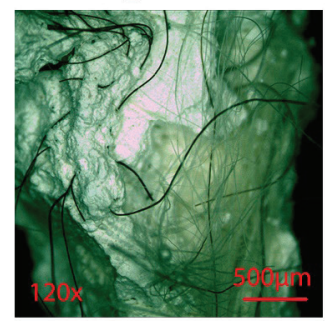

KÇC-S3b

G. 5: Karabük Çukur Camisi harç-sıva agrega (eleme öncesi) ve sıvaların polarizan mikroskop detay fotoğrafları. (M. Eroğlu, E. Yetiş, 2020)

Harç ve sıva örneklerinin element içerikleri PED-XRF ile belirlenmiştir. Bu analizlerden elde edilen sonuçlardan yola çıkarak harç ve sıva örneklerinin çimentolaşma özellikleri (CI: Cementation Index) değerlendirilmiştir. ${ }^{6}$

6 Robert S. Boynton. Chemistry and Technology of Lime and Limestone (New York: John Wiley \& Sons Inc, 1980, 275); Alkan, Çağıran, Ersan ve Eruş, Restorasyon ve Konservasyon Laboratuvarları, 77; Ayşe Gülçin 
Konfikal raman spektroskopisi (KRS) ile nokta analizi, çizgi boyu analizi ve haritalama yapılabilmektedir. Genellikle mineralojik tayinlerde nokta analizi uygulanmaktadır ${ }^{7}$. Bununla yapının duvar resimlerinde kullanılan pigment yapılarının tespiti sağlanmıştır. Boya örneklerinde kullanılan malzemenin yüzeye tutunmalarını sağlayan bağlayıcının tayin edilebilmesi için FT-IR analiz tekniğine başvurulmuştur. Bu analizde IR bölgesi MIR (mid) olan Bruker marka Alpha model FT-IR (mid) cihazıdan yararlanılmıştır. Güney ve batı duvarlarından alınan boya örneklerinde pigment ve muhtemel bağlayıcıların analizleri bu cihazlar ile yapılmıştır. Alınan kırmızı, sarı, mavi, yeşil, kahve ve siyah boya tabakası örneklerine FT-IR ve KRS analizleri uygulanmıştır.

Petrografik analizler ile harç ve sıvaların bağlayıcı-agrega oranları, içerdikleri agregaların türleri ve özellikleri belirlenerek, muhtemel kaynak alanları üzerinden öneriler geliştirilebilmektedir. Kayaçlarda ise mineral içeriği, dokusu, varsa ayrışma ve bozunma gibi durumları tespit edilerek kayacın özellikleri saptanabilmekte ve yapıda kullanılacak taş türü için önerilerde sunulabilmektedir ${ }^{8}$. Mikroskobik tanımlamada doku, bileşenler, mineraller ve tanecikler ile matriks (hamur) hakkında açıklamalar yapılmaktadir ${ }^{9}$.

Petrografik analizler kapsamında taş/kayaç, harç ve sıva örneklerinin ince kesitleri hazırlanarak optik mikroskopta incelenmiştir (G. 6). İnce kesitler; örneklerde diştan içe doğru tüm tabakaları gösterecek şekilde doğrudan hazırlanmıştır. İncelemeler LEICA marka DMLP Model alt ve üstten aydınlatmalı polarizan mikroskopta yapılmıştır. Leica marka DFC280 model dijital kamera ve Qwin programı kullanılarak fotoğrafları çekilmiştir.

Küçükkaya. Taşların Bozulma Nedenleri Koruma Yöntemleri (İstanbul: Birsen Yayınevi, 2004), 141; Ali Inal, Aydın Gunes, David J. Pilbeam, Yusuf K. Kadioglu ve Figen Eraslan. "Concentrations of Essential and Nonessential Elements in Shoots and Storage Roots of Carrot Grown in Nacl and Na2SO4 Salinity". X-Ray Spectrometry 38(1), 2009, 46; Xiuchun Zhan."Application of Polarized EDXRF in Geochemical Sample Analysis and Comparison with WDXRF". X-Ray Spectrometry 34(3), (2005), 207.

7 Kıymet Deniz, "Buzlukdağı (Kırşehir) Alkali Magmatik Kayaçların Jeolojisi, Petrolojisi ve Konfokal Raman Spektrometresi ile İncelenmesi”, (Yüksek Lisans Tezi, Ankara Üniversitesi, 2010), 63, 66-67.

8 Alkan, Çağıran, Ersan ve Eruş, Restorasyon ve Konservasyon Laboratuvarlarl, 68.

9 Alkan, Çağıran, Ersan ve Eruş, Restorasyon ve Konservasyon Laboratuvarlarl, 70; Paul F. Kerr. Optical Mineralogy. (New York: McGraw-Hill, 1977); George Rapp. Archaeomineralogy. (Berlin: Springer-Verlag, 2002). 


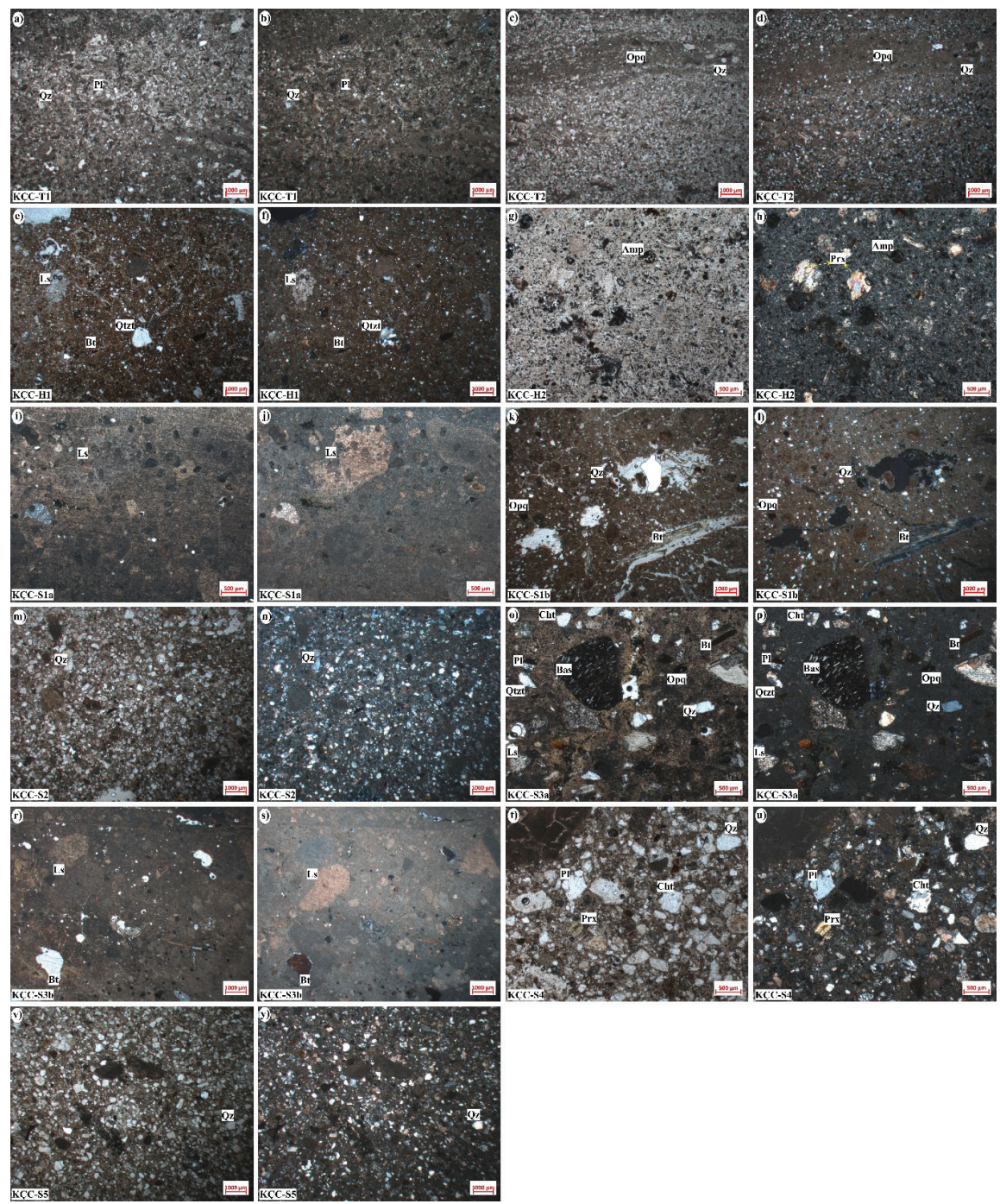

G. 6: Karabük Çukur Camisi taş, harç ve sıva örneklerinin polarizan mikroskop altında çekilmiş mikro fotoğrafları (a, c, e, g, i, k, m, o, r, t, v: paralel nikol görüntüsü, b, d, f, h, j, l, n, p, s, u, y: çapraz nikol görüntüsü), (K. Deniz, Y. K. Kadıoğlu, M. Eroğlu, 2021)

\section{Bulgular ve Değerlendirmeler}

Çalışma kapsamında Çukur Camisi'nde gerçekleştirilen malzeme analizleri sonucunda elde edilen bulgular aşağıda belirtilmektedir.

\section{Taş/Kayaçlar}

Yapıyı oluşturan tüm taş malzemeler görsel olarak benzer kayaç türünü işaret etmektedir. Bu nedenle duvarlarda kullanılan düzgün kesme ve kaba yontu taşlardan 
ikisinde mineralojik analiz ve petrografik incelemeler yapılmıştır (G. 6 a,b,c,d). Yapılan mineralojik ve petrografik incelemelere göre Çukur Camisi yerleşimi yapılarına ait 2 adet taş örneğinin de (Örnek T1 ve T2) blastopsemitik dokulu metakumtaşı olduğu tespit edilmiştir. Genel olarak kuvars, plajiyoklaz, biyotit, muskovit, serizit, zeolit, opak mineraller ile çört ve kiltaşı kaya parçalarından meydana gelmektedir (Tablo 2).

Tablo 2: Çukur Camisi taş/kayaç örneklerinin petrografik özellikleri (By:Biyotit, Ç:Çört, Ki:Kiltaşı, Mus:Muskovit, Op.Opak Mineraller, Pl: Plajiyoklas, Q: Kuvars, Sr:Serizit, Z:Zeolit), (K. Deniz, Y. K. Kadıŏglu, 2021).

\begin{tabular}{|l|c|c|c|}
\hline Taş Grupları & Kayaç Türü & Doku & Açıklamalar \\
\hline T1 ve T2 & Metakumtaşı & Blastopsemitik doku & Q, Ç, Plj, Sr, By, Mus, Z, Ki, Op. \\
\hline
\end{tabular}

\section{Harçlar ve Sivalar}

Çukur Camisi'ne ait harç ve sıva örneklerine öncelikle asit kaybı deneyi yapılmıştır. Analiz sonrasında elde edilen agregalar değerlendirilerek örneklerin asit sonrası kalan ve kayıp oranlarına ulaşılmıştır (Tablo 3). Harç örneklerinin asit kaybı deneyinden sonra çözünmeden kalan silikatlı agregaları üzerinde yapılan elek analizi sonucunda (63-1000 $\mu \mathrm{m}$ arasındaki göz açıklığına sahip elekler kullanılarak) agrega tanecik dağılımı oranları belirlenmiştir (G. 7 ve G. 8).

Tablo 3: Harç ve sıva örneklerinde agrega/bağlayıcı oranları ve elek analizi sonuçları (Tablodaki değerler elekten geçen ageregaların oranlarını belirtmektedir) (M. Eroğlu, E. Yetiş, 2021).

\begin{tabular}{|c|c|c|c|c|c|c|c|}
\hline \multirow{2}{*}{ Örnekler } & \multicolumn{2}{|c|}{ Asit Kaybı (\%) } & \multirow{2}{*}{$\begin{array}{c}>63 \mu \mathrm{m} \\
(\%)\end{array}$} & \multirow{2}{*}{$\begin{array}{c}>125 \mu \mathrm{m} \\
(\%)\end{array}$} & \multirow{2}{*}{$\begin{array}{l}>250 \mu \mathrm{m} \\
\quad(\%)\end{array}$} & \multirow{2}{*}{$\begin{array}{c}>500 \mu \mathrm{m} \\
(\%)\end{array}$} & \multirow{2}{*}{$\begin{array}{c}>1000 \mu \mathrm{m} \\
(\%)\end{array}$} \\
\hline & Кауıр & Kalan & & & & & \\
\hline H1 & 31.57 & 68.43 & 17,79 & 51,08 & 69,86 & 81,95 & 98,62 \\
\hline $\mathrm{H} 2$ & 67.91 & 32.09 & 10,68 & 16,59 & 27,60 & 54,54 & 96,21 \\
\hline S1a & 91.84 & 8.16 & 90,12 & 91,90 & 93,87 & 96,52 & 98,40 \\
\hline $\mathrm{S} 1 \mathrm{~b}$ & 37.68 & 62.32 & 10,19 & 30,99 & 57,01 & 75,68 & 94,67 \\
\hline S2 & 35.70 & 64.30 & 7,55 & 21,51 & 65,83 & 94,54 & 99,94 \\
\hline S3b & 93.14 & 6.86 & 84,50 & 87,43 & 91,28 & 94,33 & 96,57 \\
\hline S4 & 35.13 & 64.87 & 7,07 & 21,90 & 57,80 & 90,98 & 99,48 \\
\hline S5 & 34.45 & 65.55 & 7,32 & 19,73 & 53,09 & 91,33 & 99,01 \\
\hline
\end{tabular}




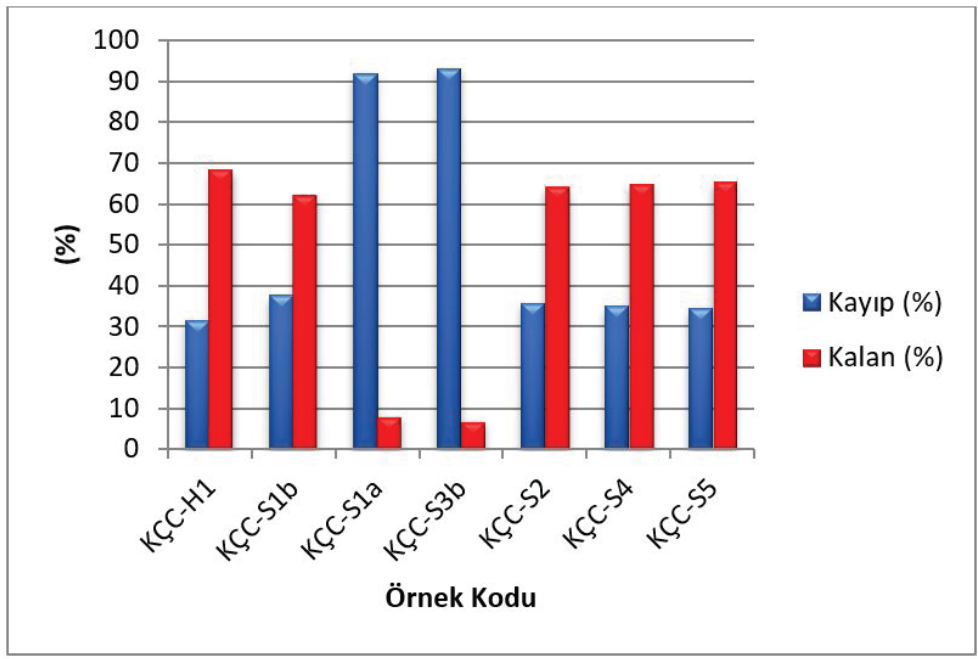

G. 7: Çukur Camisi harç ve sıva örneklerinde silikatlı agrega/bağlayıcı analiz sonuçlarını gösteren diyagram. (M. Eroğlu, 2021)

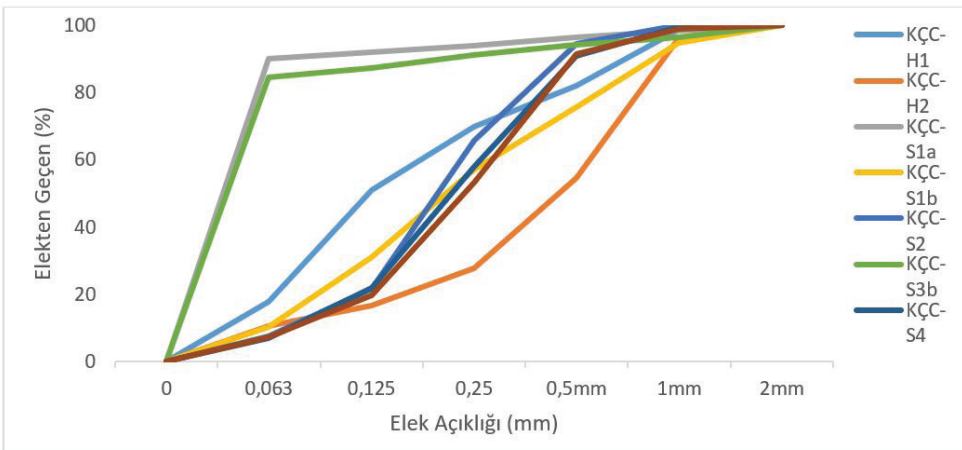

G. 8: Çukur Camisi sıva ve harç örneklerinin silikatlı agregalarında elek analizi sonuçlarını gösteren diyagram (Eroğlu, 2021)

Harç örnekleri petrografik incelemelere göre 2 grupta sınıflandırılmıştır. Buna göre; moloz dolgu harcı (kerpiç harc1/H1) ve mihrabın yapımında kullanılan (H2) harçlar farklı özellikler göstermektedir. H1 harç örneğinde agrega olarak amfibol, biyotit, kuvars, plajiyoklaz, opak mineraller ile çört, kireçtaşı, granit ve kuvarsit kaya parçacıkları, H2 harç örneğinde de kuvars, plajiyoklaz, opak mineraller ile kireçtaşı parçacıkları agrega olarak bulunmaktadır (Tablo 4). 
Tablo 4: Çukur Camisi harç örneklerinin petrografik özellikleri (B: Bağlayıc1; A: Agrega; Amf: Amfibol, By: Biyotit, Ç: Çört, G: Granit, K: Kireçtaş1, Op: Opak / Mineraller; Pl: Plajiyoklas, Qs: Kuvarsit) (K. Deniz, Y. K. Kadığlu, 2021)

\begin{tabular}{|l|c|c|l|}
\hline Harç Örnekleri & B (\%) & A (\%) & Kayaç ve Mineraller (\%) \\
\hline H1 & 35 & 65 & Amf, By, Ç, G, K, Op, Q, Qs, P1 \\
\hline H2 & 45 & 55 & Q,K, Plj, Op \\
\hline
\end{tabular}

Yüksek bağlayıcı oranına sahip olan S1a ve S3b nolu sıva örneklerinin agrega / bağlayıcı oranları ile kayaç/mineral içerikleri aynıdır. S1b örneğinin agrega / bağlayıcı oranı yaklaşık olarak 2/1 iken S3a örneğinin oranı 3/2'dır. S1b ve S3a örneklerinin kayaç ve mineral içerikleri de farklıdır. 6/1 agrega / bağlayıcı oranları ile S2, S4 ve S5 sıva örnekleri de birbirlerinin benzer oranlara sahiptir. Mihrap ortasında iki kat sıva tespit edilmiş S3a ve S3b örneklerinin; üst (bitim) ile alt kat (kaba) sıvalarının petrografik analiz sonucunda farklı agrega/bağlayıcı oranlarına sahip olduğu tespit edilmiştir (Tablo 5).

Tablo 5: Çukur Camisi sıva örneklerinin petrografik özellikleri (A: Agrega, B: Bağlayıcı, Ba: Bazalt, By: Biyotit, Ç: Çört, K: Kireçtaşı, Op: Opak Mineraller, Pl: Plajiyoklas, Py: Piroksen, Q: Kuvars, Qs: Kuvarsit), (K. Deniz, Y. K. Kadığlu, 2021)

\begin{tabular}{|l|c|c|l|}
\hline Sıva Örnekleri & B (\%) & A (\%) & Kayaç ve Mineraller \\
\hline S1a, S3b & 75 & 25 & $(\mathrm{Q}, \mathrm{Pl}, \mathrm{Op}, \mathrm{K})$ \\
\hline S1b & 35 & 65 & $(\mathrm{Q}, \mathrm{Pl}, \mathrm{C \zeta ,} \mathrm{Py,} \mathrm{By,} \mathrm{Os,} \mathrm{Op)}$ \\
\hline S3a & 40 & 60 & $(\mathrm{Ba}, \mathrm{K}, \mathrm{Q}, \mathrm{Pl}, \mathrm{C}, \mathrm{Py})$ \\
\hline S2, S4, S5 & 15 & 85 & $(\mathrm{Q}, \mathrm{Pl}, \mathrm{C \zeta}, \mathrm{By}, \mathrm{Py}, \mathrm{K})$ \\
\hline
\end{tabular}

Kimyasal bileşimlerini tespit etmek amacıyla S1a, S2 ve S4 kodlu sıva örnekleri üzerine PED-XRF analizi uygulanmış, elde edilen sonuçlara göre de kimyasal özellikleri açısından değerlendirmeleri yapılmıştır. Sıva örneklerinin PED-XRF analiziyle tespit edilen temel oksit bileşikleri ise Tablo 6' de verilmektedir.

Tablo 6: Çukur Camisi sıva örneklerinin PED-XRF analiz sonuçları (M. Eroğlu, 2021)

\begin{tabular}{|l|ccc|c|c|c|c|c|}
\hline $\begin{array}{l}\text { Temel Oksit } \\
\text { bileşikler }\end{array}$ & KÇC-H1 & KÇC-H2 & KCC-S1a & KCC-S1b & KCC-S2 & KCC-S3b & KCC-S4 \\
\hline $\mathrm{Na}_{2} \mathrm{O}$ & 0,042 & 0,15 & 0.043 & 0,047 & 0.045 & 0,045 & 0.046 \\
\hline $\mathrm{MgO}$ & 1,329 & 0,038 & 0.341 & 1,861 & 0.669 & 0,203 & 0.826 \\
\hline $\mathrm{Al}_{2} \mathrm{O}_{3}$ & 6,129 & 0,191 & 0.463 & 7,17 & 3.470 & 0.442 & 4.900 \\
\hline $\mathrm{SiO}_{2}$ & 37,27 & 0,745 & 1.730 & 29,64 & 16.63 & 1,819 & 19.51 \\
\hline $\mathrm{P}_{2} \mathrm{O}_{5}$ & 0,159 & 0,05 & 0.003 & 0,082 & 0.030 & 0,002 & 0.043 \\
\hline $\mathrm{SO}_{3}$ & 0,244 & 34,95 & 0.082 & 0,209 & 0.229 & 0,191 & 0.132 \\
\hline $\mathrm{Cl}$ & 0,072 & 0,013 & 0.027 & 0,035 & 0.056 & 0,046 & 0.036 \\
\hline $\mathrm{K}_{2} \mathrm{O}$ & 1,541 & 0,229 & 0.103 & 1,497 & 0.445 & 0,109 & 0.483 \\
\hline
\end{tabular}




\begin{tabular}{|lcc|cc|cc|c|}
\hline $\mathrm{CaO}$ & 19,6 & 27,98 & 51.14 & 20,55 & 32.62 & 50,82 & 31.57 \\
\hline $\mathrm{TiO}_{2}$ & 0,434 & 0,084 & 0.025 & 0,506 & 0.212 & 0,023 & 0.226 \\
\hline $\mathrm{V}_{2} \mathrm{O}_{5}$ & 0,014 & 0,001 & 0.006 & 0,019 & 0.008 & 0,001 & 0.005 \\
\hline $\mathrm{Cr}_{2} \mathrm{O}_{3}$ & 0,014 & 0,001 & 0.003 & 0,019 & 0.014 & 0,001 & 0.013 \\
\hline $\mathrm{MnO}$ & 0,058 & 0,004 & 0.009 & 0,074 & 0.045 & 0,009 & 0.053 \\
\hline $\mathrm{Fe}_{2} \mathrm{O}_{3}$ & 3,555 & 0,162 & 0.242 & 4,216 & 1.850 & 0,237 & 1.910 \\
\hline $\begin{array}{l}\mathrm{Kuzdirma}_{\text {Kayb1 }} \\
\text { Koplam }\end{array}$ & 29,64 & 34,92 & 45.60 & 34,84 & 43.21 & 45,98 & 40.64 \\
\hline Ton & 10,1 & 99,52 & 99.82 & 100,76 & 99.53 & 99,93 & 100.39 \\
\hline
\end{tabular}

$\mathrm{S} 1 \mathrm{a}$ sıva örneğinde; $\mathrm{CaO}$ içeriği \%51.14, $\mathrm{Al}_{2} \mathrm{O}_{3}$ içeriği \%0.463; $\mathrm{Fe}_{2} \mathrm{O}_{3}$ içeriği $\% 0.242$ ve $\mathrm{SiO}_{2} \% 1.73$ oranlarına sahip iken; $\mathrm{S} 2$ ve $\mathrm{S} 4$ sıva örneklerinde, $\mathrm{CaO}$ içeriği \%31.57-32.62, $\mathrm{Al}_{2} \mathrm{O}_{3}$ içeriği \%3.47-4.90, $\mathrm{Fe}_{2} \mathrm{O}_{3}$ içeriği \%1.85-1.91 ve $\mathrm{SiO}_{2}$ içeriği \%16.63-19.51 aralığındadır. Buna göre $\mathrm{S} 2$ ve $\mathrm{S} 4$ örneklerin $\mathrm{CaO}, \mathrm{Al}_{2} \mathrm{O}_{3}, \mathrm{Fe}_{2} \mathrm{O}_{3}$ ve $\mathrm{SiO}_{2}$ değerleri $\mathrm{S} 1 \mathrm{a}$ örneğinden farklı olup bu farklılık çimento bağlayıcısının kimyasal kompozisyonundan kaynaklanmakta olduğu fikrini akla getirmektedir (Tablo 7). Portland çimentosu ile ilgili analiz çalışmasından elde edilen değerler ile S2 ve S4 sıva örneklerinin değerleri birbirleriyle uyumludur ${ }^{10}$. Analizleri yapılan sıva örnekleri kimyasal içeriklerine ve oksit bileşik oranlarına göre Keily diyagramında gösterilerek gruplandırılmış ve hidrolik özellikleri değerlendirilmiştir (G. 9).

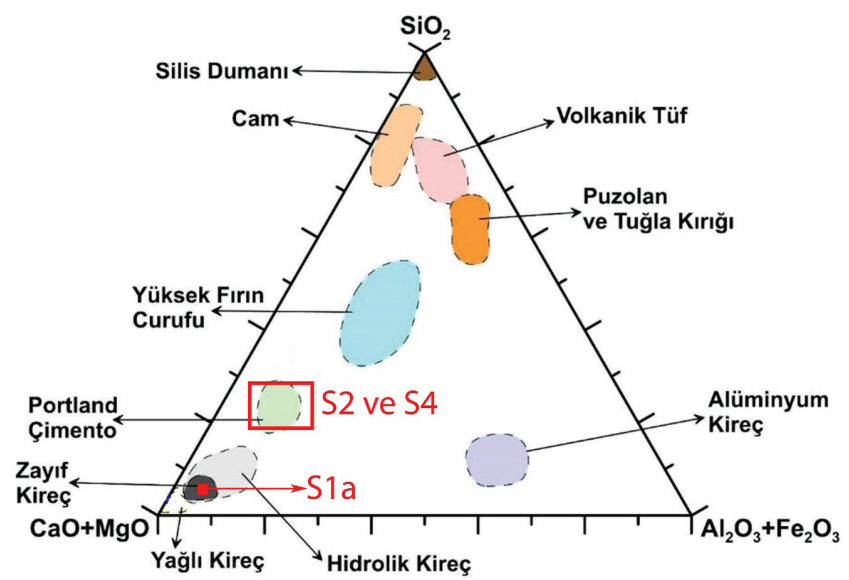

G. 9: Çukur Camisi S1a, S2 ve $\mathrm{S} 4$ nolu sıva örneklerinin Keily diyagramındaki $(\mathrm{CaO}+\mathrm{MgO}-$ $\mathrm{SiO} 2-\mathrm{Al} 2 \mathrm{O} 3+\mathrm{Fe} 2 \mathrm{O} 3$ ) konumlar1 (M. Ndiaye, M. Diop ve P. M. Ngom. "Pozzolanic Activity of Acidic and Intermediate Volkanic Tuffs of Mako Areas (Senegal)", E Yüzer, H. Ergin ve A. Tuğrul (Ed.). International Symposium on Industrial Minerals and Building Stones (IMBS'2003), İstanbul: Kelebek ve Grafika Grup, 2003, 5199).

10 Murat Aydın, "Kalsiyum Alüminat Çimentosu İle Portland Çimentosunun Karşılaştırılması", (Yüksek Lisans Tezi, Çukurova Üniversitesi, 2019), 25. 
Tablo 7: Çimentolaşma İndeks değerleri (Robert S. Boynton. Chemistry and Technology of Lime and Limestone. New York: John Wiley \& Sons Inc, 1980,275)

\begin{tabular}{|l|c|}
\hline Kireç Türü & Çimentolaşma İndeksi (CI) \\
\hline Kaymak (Yağl1) Kireç-YK (Sllaked (Fat) Lime) & $<0.30$ \\
\hline Zayıf Hidrolik Kireç-ZHK (Weakly Hydraulic Lime) & $0.30-0.50$ \\
\hline Ortalama Hidrolik Kireç-OHK (Moderately Hydraulic Lime) & $0.51-0.70$ \\
\hline Hidrolik Kireç-HK (Eminently Hydraulic Lime) & $0.71-1.10$ \\
\hline Doğal Çimento-DÇ (Natural Cement) & $1.11-1.70$ \\
\hline Doğal Çimento/Çimento-DÇ/Ç (Natural Cement/Cement) & $1.70<$ \\
\hline
\end{tabular}

Tablo 8: Çukur Camisi Sıva örneklerinin hesaplanan çimentolanma indeks değerleri (Robert S. Boynton. Chemistry and Technology of Lime and Limestone. (New York: John Wiley \& Sons Inc, 1980,275)

\begin{tabular}{|l|l|l|}
\hline Örnek & CI & Bağlayıcı Türü \\
\hline S1a & 0.11 & YK \\
\hline S3b & 0.11 & YK \\
\hline S2 & 1.56 & $\mathrm{DÇ/Ç}$ \\
\hline S4 & 1.89 & $\mathrm{DÇ/Ç}$ \\
\hline
\end{tabular}

Sıvanın kimyasal bileşim özellikleri çimentolanma indeks (CI) verileri yardımı ile değerlendirilmiştir. Çimentolaşma indekslerine göre sıva numuneleri içerisinde; S1a ve S3b örneklerinin hava kireci (YK; yağlı kireç), S2 ile S4 örneklerinin ise doğal çimento (DÇ) ve çimento (Ç) bağlayıcısı kullanılarak üretildikleri anlaşılmaktadır. Keily Diyagramına göre de S1a örneği yağlı (hava) kireç, S2, S4 örnekleri de Portland çimento grubu ile eşleşmektedir (G. 9, Tablo 7 ve Tablo 8).

Benzer yapı özellikleri gösteren Safranbolu evleri Unesco kültür mirası kapsamında olmakla beraber, literatürde bu evlerin malzemesine yönelik çok fazla çalışma da bulunmamaktadır ${ }^{11}$.

Genel olarak batı duvarında minber arkasında özgün sıva kısmen korunmuş; duvarın diğer kısımlarında ise dökülerek tahrip olmuştur. Dökülen kısımlarda yapının duvar örgü sistemi ve sıva katmanları belirlenmiştir. Yapının diğer duvarlarında önceki onarım sıvaları ve üzerindeki kalem işleri mevcut olduğu için örnek alınmamış, ancak batı duvarı ile benzer özelliklere sahip olduğu görsel olarak belirlenmiştir.

Agregaların hapsi $1000 \mu$ m’un üzeri gözlü (2-1mm arası) elekten geçmiştir. Buna göre agregalar 1mm'nin altında boyuta sahiptirler. H1 killi kerpiç harcıdır, \%35 bağlay1c1, \%65 agregaya sahiptir. Bu agrega da asit sonrası kalan \%83 kum ve \%17 (kil+silt)

11 Ali Akın Akyol ve Murat Eroğlu, 21. Yüzyılda Türk Sanatı: Meseleler ve Çözüm Önerileri (Kastamonu: Kastamonu Üniversitesi Yayınları, 2018), Erişim 25 Mayıs 2021, https://gstf.kastamonu.edu.tr/index.php/tr/ bilgi-sistemleri/haberler-tr/3198-21 
değerlerine göre, kil+siltli kumdur. S1b kil+saman+kıtık katkılıdır. \%35 bağlayıc1, \%65 agregaya sahiptir. Bu agreganın da asit sonrası kalan \%90 kum ve \%10 ( kil+silt) değerlerine göre kil+siltli kumdur. $\mathrm{H} 2$ harcı alçı içerikli bağlayıcıya sahiptir. $\% 45$ bağlayıcılı ve $\% 55$ agregadan oluşmaktadır. Bu agrega ise, asit sonrası kalan $\% 90$ kum ve $\% 10$ (kil+silt) değerlerine göre kil+siltli kumdur. S1a kireç+kıtık katkılı \%75 bağlayıcılı ve $\% 25$ agregadan oluşan sıvadır. Agrega, asit sonrası kalan \%90 (kil+silt) ve \%10 kum değerlerine göre kumlu kil+siltdir. S3b kireç+kıtık katk11 \% $\% 5$ bağlayıcı ve $\% 25$ agregadan oluşan bir sıvadır. Agrega, asit sonrası kalan \%85 ( kil+silt), \%15 kum değerlerine göre kumlu kil+siltdir. S2, S4 ve S5 sivaları \%15 bağlayıc1 ve \%85 agregadan oluşmaktadır. Agrega, asit sonrası kalan \%93 kum, \%7 ( kil+silt) değerlerine göre kil+siltli kumdur. Elek analizi sonuçlarına göre silikatlı agregaları en ince olan sıvalar S1a ve S3b, en kalın olanı H2 harcıdır. H1 harcının silikatlı agregaları S1b sıvasından daha ince; S2, S4 ve S5 sıvalarında ise kendi içerisinde uyumludur (Tablo 3, G. 7 ve G. 8).

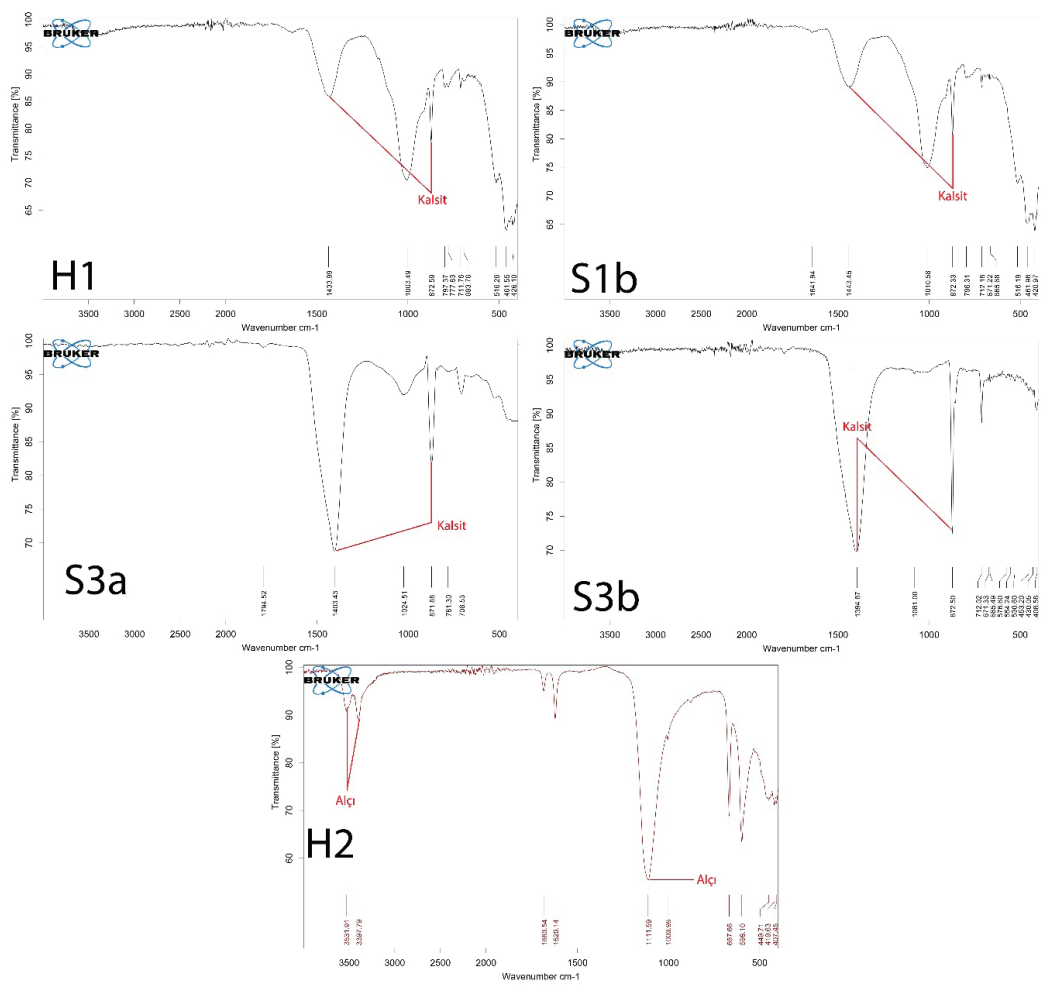

G. 10: Çukur Camisi harç ve sıva örneklerinin FT-IR spektrumları (E.Yetiş, 2021).

H1, H2, S1b, S3a ve S3b harç ve sıva örneklerinin FT-IR spektrumları incelenmiştir. Mihrabın çerçevesinden alınan H2 örneğinde alçı kullanımına işaret eden kuvvetli 1140- 
$1080 \mathrm{~cm}^{-1}$ ve 3700-3200 $\mathrm{cm}^{-1}$ karakteristik bantlar ${ }^{12}$ görülmektedir. Diğer örneklerden S3a ve S3b'de oldukça kuvvetli $1490-1370 \mathrm{~cm}^{-1}$ ve $910-850 \mathrm{~cm}^{-1}$ karakteristik kireç ${ }^{13}$ bantları görülürken, H1 ve S1b örneklerinde kireç bantları oldukça zayıftır (G. 10).

\section{Boyalar}

FT-IR analizleri öncesinde; P1a, P2a, P2b, P3a, P3c, P4, P5a, P5a ve P5b numunelerinin boya tabakalarından, ince boya katmanını aşmadan kazıma yapılarak analize uygun hâle getirilmeye çalışılmıştır. Daha iyi sonuç alabilmek için kazıyarak alınan parçalar ezilerek toz hâline getirilmiş ve cihazın örnek tutucu haznesine göre hacimsel olarak yaklaşık 0.05 ml'lik miktarda numune cihaza yerleştirilmiştir.

FT-IR analizlerinde araştırılan bağlayıcı maddeler genel olarak yağlar/vakslar, proteinler, şekerler/nişastalar ve reçineler olmak üzere dört ana grupta toplanmıştır ${ }^{14}$. IR analizlerinde gerilme ve bükülme titreşimleri söz konusu organik maddelerin belirlenmesinde genel bir kabul oluşturmuştur. Ayrıca birçok tarihi malzemenin FT-IR verilerini içeren veri tabanından ${ }^{15}$ faydalanılmıştır. Bununla birlikte FT-IR ile yapılan organik madde tespitleri genellikle bir ön araştırma niteliğindedir. Ön inceleme sonuçlarını takiben kromatografik yöntemler ile incelemeler yapılmaktadır ${ }^{16}$.

P1a, P2a, P2b, P3a, P3c, P5a, P5b ve P4 örneklerinde yapılan FT-IR analizlerinde 910-850 $\mathrm{cm}^{-1}$ ve 1490-1390 $\mathrm{cm}^{-1}$ bantlarındaki piklerin kuvvetli olduğu görülmektedir $^{17}$. Bu bantlar kalsiyum karbonat $\left(\right.$ Kalsit- $\left.\mathrm{CaCO}_{3}\right)$ varlığına işarettir. Kalsiyum karbonat gerilmeleri örneklerdeki organik varlığının araştırılmasını zorlaştırmaktadır. Ancak grafiklerde kalsit titreşimlerinin bulunduğu bantlar arasındaki şiddetsiz pikler organik maddeler üzerinde tahmin yürütülmesini sağlamıştır (G. 11).

12 Michele R. Derrick, Dusan Stulik, James M. Landry, Infrared Spectroscopy in Conservation Science Scientific Tools for Conservation, (Los Angeles: The Getty Conservation Institute, 1999), 194.

13 Michele R. Derrick, Dusan Stulik, James M. Landry, Infrared Spectroscopy in Conservation Science Scientific Tools for Conservation,194.

14 Irmina Zadrożna, Kasia Połeć-Pawlak, Iwona Głuch, Mohamed A. Ackacha, Mirosław Mojski, Janina Witowska-Jarosz ve Maciej Jarosz. "Old Master Paintings- A Fruitful Field of Activity for Analysts: Targets, Methods, Outlook”. Journal of Separation Science 26, (2003), 996-1004; Ezgin Yetiş, "Tarihi Duvar Resimlerinde Kullanılan Boya Ve Bağlayıcılar”, ed. C. Ünal ve C. Gürbıyık Uluslararası XIX. Ortaçă̆ ve Türk Dönemi Kazıları ve Sanat Tarihi Araştırmaları Sempozyumu C. 2 (Ankara: Türk Tarih Kurumu Yayınları. 2019), 507-530.

15 Database of ATR-FT-IR spectra of various materials. Erişim 11 Eylül 2020. http://lisa.chem.ut.ee/IR_spectra/ ; Signe Vahur, Anu Teearu, Pilleriin Peets, Lauri Joosu ve Ivo Leito. “ATR-FT-IR spectral collection of conservation materials in the extended region of 4000-80 cm $\mathrm{cm}^{-1}$. Anal Bioanal Chem 408, (2016), 3373-3379.

16 Derrick, Stulik, Landry, Infrared Spectroscopy in Conservation Science Scientific Tools for Conservation, 17-18.

17 Derrick, Stulik, Landry, Infrared Spectroscopy in Conservation Science Scientific Tools for Conservation, 194 Vahur, "ATR-FT-IR spectral collection of conservation materials in the extended region of $4000-80 \mathrm{~cm}^{-1}$ ", 3377 . 
Sıva üzerine uygulanan boyaların FT-IR analizlerinde sıvada bulunan kireç, kil ve bazı tuzlardan kaynaklı değerlerine dikkat edilmelidir. Ancak organik bağlayıcı maddelerin daha doğru ve temiz FT-IR sonuçlarına ulaşılabilmesi için, hazırlanan numunelerin içerisinde bulunan çeşitli tuz bileşikleri, kireç vb. duvar resmi yapım malzemelerinden ayrıştırılması gerekmektedir ${ }^{18}$.

Duvar resimlerinde bazen tek bir bağlayıcı türünün kullanılmadığı görülmektedir. Protein esaslı bir bağlayıcı ile birlikte yağ esaslı bir bağlayıcı da kullanılmış olma olasılığ 1 yüksektir ${ }^{19}$. Bu sebeple organik örneklerde IR spektrum bantları, özel atom gruplarının karakteristik bantları olup, bağlayıcıların tayininde önemli ipuçları vermektedir ${ }^{20}$. Bu sebeple bağlayıcı tespitinde bir ön araştırma niteliğindedir

Karbonil bantlarının görüldüğü $1630-1750 \mathrm{~cm}^{-1}$ aralığına tüm örneklerde rastlanmaktadır. P1a, P2a, P2b ve P5a örneklerinde protein varlığını destekleyebilecek 1630$1680 \mathrm{~cm}^{-1}$ bant aralığ 1 görülmektedir. Ancak bunlardan protein varlığını destekleyebilecek karakteristik pikler olan $1520-1560 \mathrm{~cm}^{-1}, 1450 \mathrm{~cm}^{-1}, 1240 \mathrm{~cm}^{-1}, 1080 \mathrm{~cm}^{-1}$ ve $3300 \mathrm{~cm}^{-1}$ bantlarını karakteristik kireç $\left(1490-1370 \mathrm{~cm}^{-1}\right.$ ve $\left.910-850 \mathrm{~cm}^{-1}\right)$ pikleri örtmektedir. Bununla birlik P1a örneğinde 1630-1680 cm-1 aralığ 1 ile $1715-1740 \mathrm{~cm}^{-1}$ ve bunu destekleyen simetrik 2920-2934 cm-1, 2855-2860 $\mathrm{cm}^{-1}$ gomalak kullanımına işaret edebilir. P2b örneğindeki zayıf 1630-1750 $\mathrm{cm}^{-1}$ bantlarının olması, simetrik $3400 \mathrm{~cm}^{-1}$ ve $1068-1100 \mathrm{~cm}^{-1}$ polisakkarit kaynaklı bağlayıcı (gum) kullanımını gösterebilir. P2b, P3a, P4, P5a ve P5b örneklerindeki $1795 \mathrm{~cm}^{-1}$ band1 ise kalsiyum oksalat $\left(\mathrm{CaC}_{2} \mathrm{O}_{4}\right)$ veya sülfattan $\left(\mathrm{SO}_{4}{ }^{2}\right)$ kaynaklanan tuzlanmayı gösterebilir. $\mathrm{P} 4$ haricindeki örneklerde yer alan 2920-2960 cm-1 ve 2850-2875 cm-1 bantlar1 kuruyan yağlar, protein (yumurta) $)^{21}$ ve hayvansal/bitkisel reçinelerin kullanımını düşündürür ${ }^{22}$. Diğgerlerinden farklı olan P4 örneğinde $1790 \mathrm{~cm}^{-1}$ üzerinde piklerin olmaması, çimento içerikli yakın dönem sıvası üzerinde bulunması sebebi ile de, akrilik kaynaklı boyaların kullanıldığına işaret etmektedir ${ }^{23}$ (G. 11).

18 Ahmet Güleç, "Süleymaniye Camii Kalemişi Boyalarının Analizleri". Vakıf Restorasyon Yıllığı 3 (2011), 113-122; A. Sarmiento, M. Pérez Alonso, M. Olivares, K.Castro, I. Martínez-Arkarazo, L. Fernández, ve J. Madariaga. "Classification and Identification of Organic Binding Media in Artworks by Means of Fourier Transform Infrared Spectroscopy and Principal Component Analysis". Analytical and Bioanalytical Chemistry 399 (2011), 3601-3611.; Corso vd., 2012: 3011-3016)

19 Francesca Rosi, Alessia Daveri, Costanza Miliani, Giovanni Verri, Paolo Benedetti, Francesca Pique, Bruno Brunetti ve A Sgamellotti. "Non-invasive identification of organic materials in wall paintings by fiber optic reflectance infrared spectroscopy: A statistical multivariate approach". Analytical and bioanalytical chemistry 395. (2009), 2097-2106; Gaetano Corso, M. Gelzo, C. Sangers, A. Chambery, A. Di Maro, V. Severino, A. D. Russo, C. Piccioli, P. Arcari. "Polar and non-polar organic binder characterization in Pompeian wall paintings: comparison to a simulated painting mimicking an "a secco" technique". Anal Bioanal Chem 402, (2012), 3011-3016.

20 Tuba Büyüksırt, Hakan Kuleaşan. "Fourier Dönüşümlü Kizilötesi (FTIR) Spektroskopisi ve Gıda Analizlerinde Kullanımı". Glda 39 (2014), 237.

21 Yumurta sarısı beyazına göre yağ içerdiği için yumurta sarısının spektrumu yağlara yakındır.

22 Michele R. Derrick, Dusan Stulik, James M. Landry, Infrared Spectroscopy in Conservation Science Scientific Tools for Conservation, (Los Angeles: The Getty Conservation Institute, 1999), 94-112.

23 Michele R. Derrick, Dusan Stulik, James M. Landry, Infrared Spectroscopy in Conservation Science Scientific Tools for Conservation, (Los Angeles: The Getty Conservation Institute, 1999), 111. 

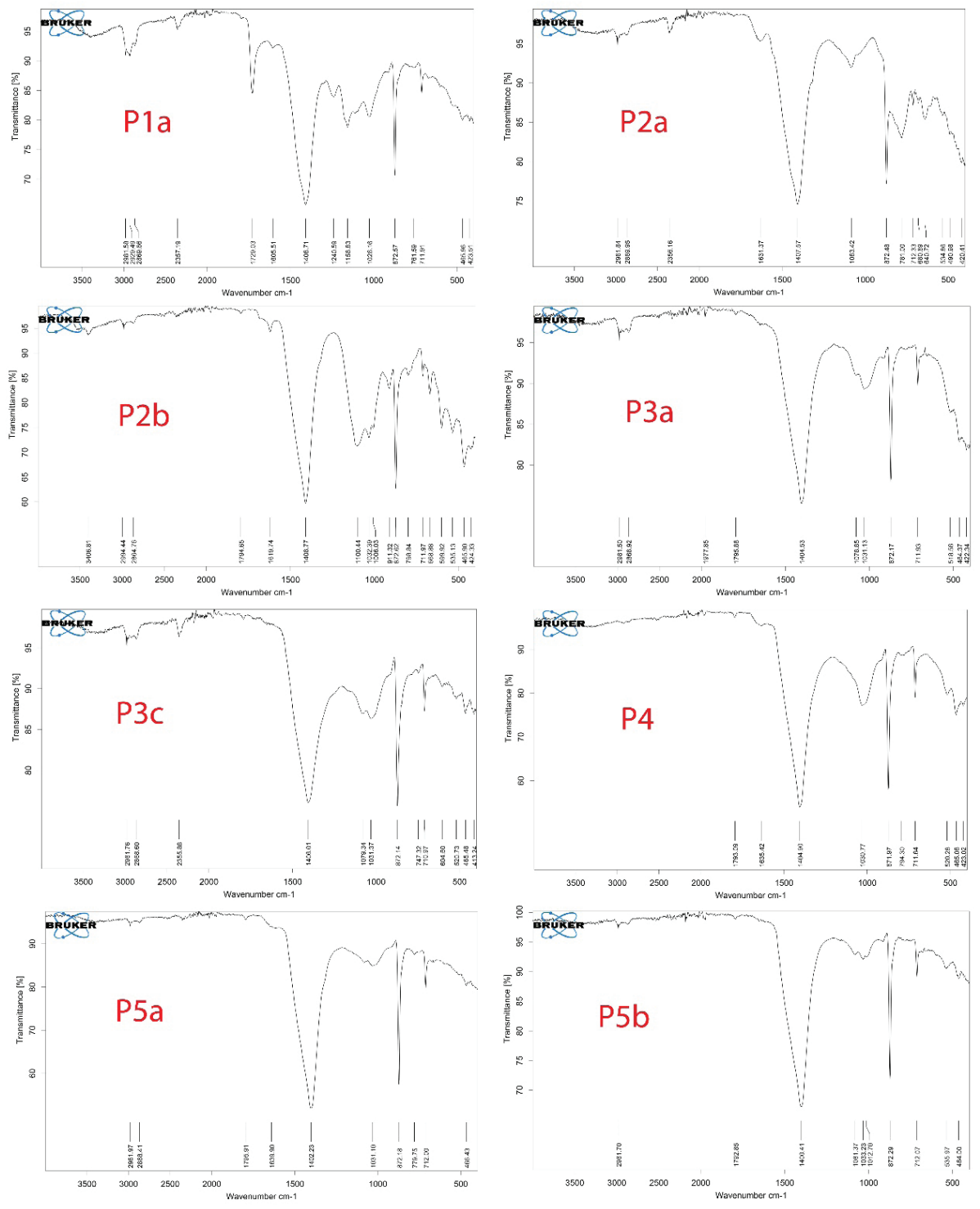

G. 11: Çukur Camisi boya örneklerinin FT-IR spektrumları (E.Yetiş, 2021).

P2a, P2b, P5a ve P5b örneklerine KRS analizi yapılmıştır. Minber arkasındaki duvar üzerine uygulanmış siyah renkli P5a örneğinde karbon (C), kırmızı renkli $\mathrm{P} 5 \mathrm{~b}$ örneğinde ise hematit $\left(\mathrm{Fe}_{2} \mathrm{O}_{3}\right)$ tespit edilmiştir. Mihraptan alınan sıvanın üzerindeki yeşil renkli $\mathrm{P} 2 \mathrm{a}$ örneğinde olivin $\left([\mathrm{Mg}, \mathrm{Fe}] 2 \mathrm{SiO}_{4}\right)$ ve krom sarısı $\left(\mathrm{PbCrO}_{4}\right)$, kahvemsi sarı renkli $\mathrm{P} 2 \mathrm{~b}$ örneğinde ise götit $(\mathrm{FeO}[\mathrm{OH}])$ kaynaklı pigmentler belirlenmiştir (G. 12). 
Minber arkasındaki P5a örneğindeki karbon (C) kaynaklı siyah pigmentinin kullanımı oldukça eskilere- tarihöncesine kadar- dayanmaktadır. Pigmentler genel olarak toprak kaynaklardan ve odun kömüründen elde edilirken, antik dönemden itibaren kemik siyahı, fildişi siyahı ve is kullanımı yaygınlaşmıştır. Yine minber arkasından alınan P5b örneğindeki hematit $\left(\mathrm{Fe}_{2} \mathrm{O}_{3}\right)$, doğal olarak bulunan ve demir (III) oksit olarak bilinen pigmenttir ${ }^{24}$. Mihrap içinden alınan P2a örneğindeki yeşil rengi veren olivin minerali ([Mg,Fe]2SiO 4 ) ve P2b'deki götit minerali (FeO[OH]) doğal kaynaklı pigmentlerdir. P2a örneğinde tespit edilen krom sarısının (kurşun kromat) yeşil renkli olivin $\left([\mathrm{Mg}, \mathrm{Fe}] 2 \mathrm{SiO}_{4}\right)$ kaynaklı pigment ile karıştırılarak sıcak bir yeşil elde edilmek istendiği düşünülmektedir.

Krom sarıs1 $\left(\mathrm{PbCrO}_{4}\right)$ olarak bilinen pigmentin krokoit mineralinin keşfinden sonra yapay olarak elde edildiği söylenmektedir. 1810 yılından sonra kullanılmaya başlanmış ve günümüzde de kullanımı devam etmektedir ${ }^{25}$.

Literatürdeki kahveye yakın sarı renkli sarı okra pigmenti, götit ( $\mathrm{FeO}[\mathrm{OH}])$ kaynakl1dır. Götit mineralinin, doğal kaynaklı olarak tarih öncesinden beri kullanıldığı bilinmektedir. Ancak götit yerine 1920 yılından sonra yapay olarak "mars yellow" adı ile bilinen pigment olarak kullanılmaya devam edilmiştir ${ }^{26}$. KRS sonuçlarına göre; sarı okra pigmentinin doğal kaynaklı götit $(\mathrm{FeO}[\mathrm{OH}])$ mineralinden elde edildiği düşünülmektedir.

24 Paolo Mora, Laura Mora ve Paul Philippot. Conservation of Wall Paintings. (London: Butterworths, 1984), 64-66; Ezgin Yetiş, "Tarihi Duvar Resimlerinde Kullanılan Boya ve Bağlayıcılar”, 515-516, 521-523; Database of ATR-FT-IR spectra of various materials.

25 Mora, Mora ve Philippot, Conservation of Wall Paintings 64-66; Yetiş, "Tarihi Duvar Resimlerinde Kullanılan Boya ve Bağlayıcılar”, 514, 521-523; Pigments Through the Ages. Erişim 01 Ekim 2020. http://www. webexhibits.org/pigments/

26 Pigments Through the Ages. 


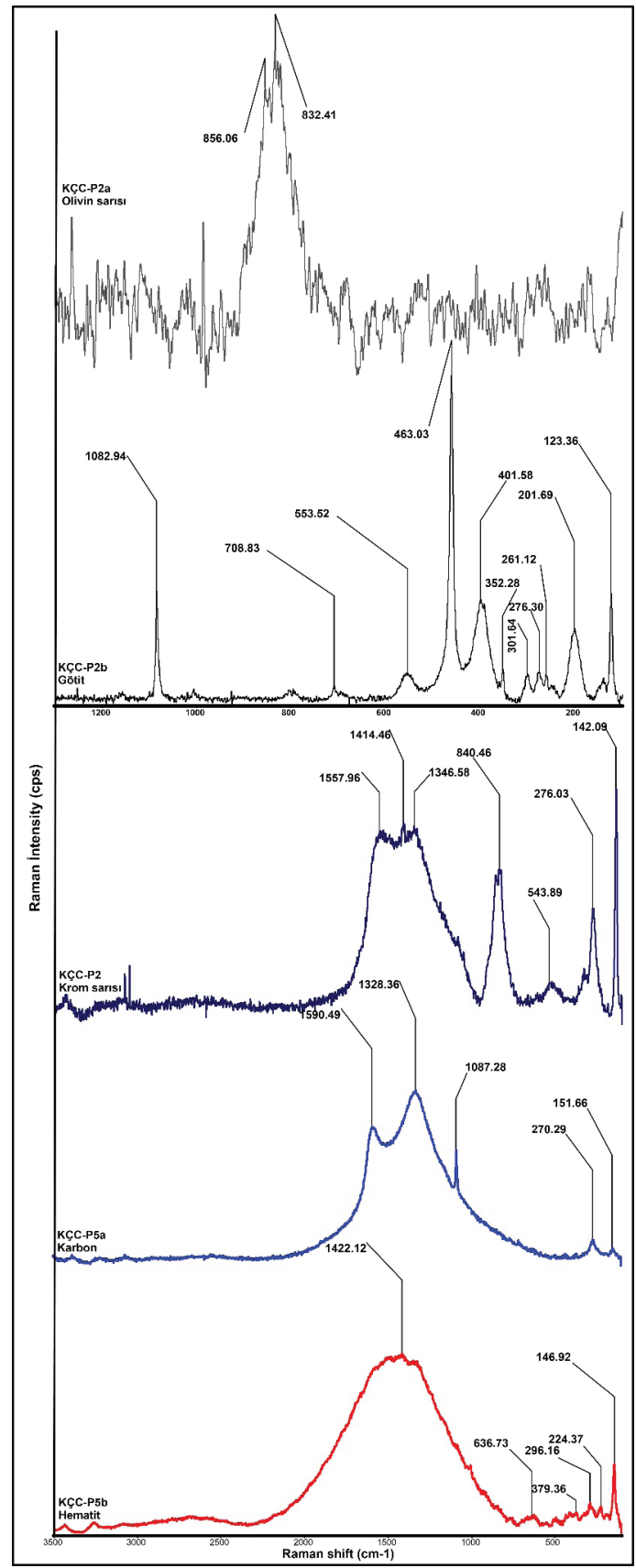

G. 12: Çukur Camisi bazı boya örneklerinin KRS spektrumları (K. Deniz, 2021). 


\section{Tartışma}

“Karabük, Ovacık Çukur Camisi Yapı Malzemelerinin Analizleri” kapsamında gerçekleştirilen örnekleme ile 2 adet taş, 12 adet harç, 5 adet sıva ve 12 adet boya malzemesinden oluşan örnekler üzerinde incelemeler yapılmıştır.

Tablo 9: Çukur Camisi yapı malzemeleri örneklerini birlikte bulundukları duvar, sıva ve boya katmanları ile gösterimi (E. Yetiş, M. Eroğlu 2021)

\begin{tabular}{|c|c|c|c|c|c|}
\hline & DUVAR & \multicolumn{2}{|l|}{ SIVA } & \multicolumn{2}{|r|}{ BOYA } \\
\hline \multirow[t]{2}{*}{$\begin{array}{l}\text { GÜNEY } \\
\text { DUVARI } \\
\text { (MİHRAP) }\end{array}$} & \multirow[t]{2}{*}{$\begin{array}{c}\mathrm{T} 1 \\
\text { (Metakumtaşı) }\end{array}$} & \multirow{2}{*}{$\begin{array}{c}\text { S3b (A/B: \% 25/75) } \\
\text { (Kireç bağlayıcı+kıtık) } \\
\text { (Kum+kil+silt agregalı) }\end{array}$} & \multirow[t]{2}{*}{$\begin{array}{c}\text { S3a (A/B: \% } \\
60 / 40)\end{array}$} & \multicolumn{2}{|c|}{\begin{tabular}{c|c} 
P2a & Olivin+ \\
& Krom \\
Kırmız1
\end{tabular}} \\
\hline & & & & $\mathrm{P} 2 \mathrm{~b}$ & Götit \\
\hline $\begin{array}{l}\text { GÜNEY } \\
\text { DUVARI } \\
\text { (MİHRABIN } \\
\text { DIŞ } \\
\text { ÇERÇEVESI) }\end{array}$ & $\begin{array}{c}\mathrm{H} 2 \text { (A/B: \% } \\
55 / 45) \\
\text { (Alçı } \\
\text { bağlayicılı) } \\
\text { (Kil+silt+kum } \\
\text { agregalı) }\end{array}$ & & & & \\
\hline \multirow{4}{*}{$\begin{array}{l}\text { GÜNEY } \\
\text { DUVARI } \\
\text { (SAĞ } \\
\text { PENCERE } \\
\text { ALTI) }\end{array}$} & \multirow{4}{*}{ - } & \multirow{4}{*}{\multicolumn{2}{|c|}{$\begin{array}{c}\text { S2 (A/B: \% 85/15) } \\
\text { (Çimento bağlayıc1lı) } \\
\text { (Kil+silt+kum agregalı) }\end{array}$}} & P1a & - \\
\hline & & & & - & \\
\hline & & & & - & \\
\hline & & & & - & \\
\hline \multirow[b]{2}{*}{$\begin{array}{l}\text { BATI DUVARI } \\
\text { (MINBER } \\
\text { ARKASI) }\end{array}$} & \multirow{2}{*}{$\begin{array}{c}\text { H1 (A/B: \% } \\
\text { 65/35) } \\
\text { (Kil bağlayicıli) } \\
\text { (Kil+silt+kum } \\
\text { agregalı) }\end{array}$} & \multirow[b]{2}{*}{$\begin{array}{c}\text { S1b (A/B: \% 65/35) } \\
\text { (Kil bağlayıc1+saman+kıtık) } \\
\text { (Kil+silt+kum agregalı) }\end{array}$} & \multirow[b]{2}{*}{$\begin{array}{c}\text { S1a (A/B: \% } \\
\text { 25/75) } \\
\text { Kireç } \\
\text { bağlayıc1+kıtık) } \\
\text { (Kum+kil+silt } \\
\text { agregalı) }\end{array}$} & P5a & Karbon \\
\hline & & & & P5b & Hematit \\
\hline \multirow{3}{*}{ BATI DUVARI } & \multirow{3}{*}{ - } & \multirow{3}{*}{\multicolumn{2}{|c|}{$\begin{array}{c}\text { S4 (A/B: \% 85/15) } \\
\text { (Çimento bağlayıc1lı) } \\
\text { (Kil+silt+kum agregalı) }\end{array}$}} & P3a & - \\
\hline & & & & - & \\
\hline & & & & - & \\
\hline \multirow[t]{2}{*}{$\begin{array}{l}\text { KUZEY } \\
\text { DUVARI }\end{array}$} & - & $\begin{array}{r}\text { S5 (A/B: \% } 85 \\
\text { (Çimento bağla } \\
\text { (Kil+silt+kum ag }\end{array}$ & $\begin{array}{l}\text { 15) } \\
\text { c1li) } \\
\text { egal1) }\end{array}$ & P4 & - \\
\hline & DUVAR & SIVA & & & BOYA \\
\hline
\end{tabular}

Yapının iç cephesindeki batı, güney ve kuzey duvarlarından sıvaların döküldüğü yerlerden örnekler alınabilmiş, doğu duvarından örnekleme yapılmamıştır. Ancak görsel olarak incelendiğinde doğu duvarı ile diğer duvarların benzer özellikler içerdiği belirlenmiştir. Yapıdan alınan düzgün kesme taş ile kaba yonu taş örnekleri birbirleri ile aynı olup petrografik analize göre metakumtaşı olarak tanımlanmıştır. Metakumtaşları meta- 
morfizmaya uğramış kumtaşlarıdır. Çukur Camisi'nin bulunduğu köy ve çevresinde metamorfik kayaçlar tespit edilmemiştir. Bölgede metamorfik kayaçlar Ovacık’tan yaklaşık 30 km doğuda, Soğanlı Çayı'nın da doğusunda Çavuşlar köyü çevresinde belirlenmiştir. Ayrıca harç ve sıva içerindeki agregaların bir kısmında metamorfik kayaçlardan kuvarsit ve magmatik kayaçlardan bazalt ve granit kaya parçaları tespit edilmiştir. Bu kayaçlar da gene aynı bölgede Ovacık'ın doğusunda Soğanlı Çayı'nın dere yatağının geçtiği yerdeki Granitoid ve Ofiyolitlerle ilişkili olmalıdır. Soğanlı Çayı bu bölgeden batıya doğru devam edip Çukur köyünün yaklaşık 2 km kuzeyinden geçmektedir. Sıva ve harç içerisine katılan agregalar da bu bölgedeki dere yatağı ile ilgili olabilir2 ${ }^{27}$.

Batı duvarında iki çeşit sıva tespit edilmiştir. Bunlardan birincisi minberinin arkasında kalan kısımda bulunan sıvadır ve iki katmandan oluşmaktadır. Bu sıvanın alt katmanındaki (S1b)- moloz dolguda kullanılan killi kerpiç harcı (H1) ile benzer olarak- taş duvar üzerinde kil+saman-kıtık katkılı sıvadır. Üst katmanındaki de kireç+kıtık içeren (S1a) ince sıvadır. Burada belirlenen kaba kil+saman-kıtık içerikli sıva zaman içerisinde dökülmüş olmalıdır, diğer duvarlarda bu sıva kaldırılarak yeni sıva yapılmış, minber arkasındaki özgün sıva korunmuştur (Tablo 9 ve 10).

Tablo 10: Çukur Camisi yapı malzemeleri örneklerinin genel analiz tablosu (petrografi hariç). (M. Eroğlu, E. Yetiş, 2021)

\begin{tabular}{|l|l|c|c|c|c|}
\hline Kod & $\begin{array}{l}\text { Yapılan } \\
\text { analizler }\end{array}$ & $\begin{array}{c}\text { Harç-Sıva } \\
\text { ozzelliği }\end{array}$ & $\begin{array}{c}\text { Pigment } \\
\text { özelliği }\end{array}$ & Resim Tekniği & Bağlayıcı Özelliği \\
\hline H1 & $\begin{array}{l}\text { FT-IR, PED- } \\
\text { XRF }\end{array}$ & Kireç (zayıf bant) & - & - & - \\
\hline H2 & $\begin{array}{l}\text { FT-IR, PED- } \\
\text { XRF }\end{array}$ & Alçı & - & - & - \\
\hline S1a & PED-XRF & Kireç & - & - & - \\
\hline S1b & $\begin{array}{l}\text { FT-IR, PED- } \\
\text { XRF }\end{array}$ & Kireç (zayıf bant) & - & - & - \\
\hline S2 & PED-XRF & Çimento (?) & - & - & - \\
\hline S3a & FT-IR & Kireç & - & - & - \\
\hline S3b & $\begin{array}{l}\text { FT-IR, PED- } \\
\text { XRF }\end{array}$ & Kireç & - & - & - \\
\hline S4 & PED-XRF & Çimento (?) & - & - & - \\
\hline P1a & FT-IR & - & Belirsiz & Belirsiz & $\begin{array}{c}\text { Organik: } \approx \text { reçine/pro- } \\
\text { tein/yağ }\end{array}$ \\
\hline P2a & FT-IR, KRS & - & Olivin+ Krom & Kuru Sıva & Organik: $\approx$ protein/yăg \\
\hline P2b & FT-IR, KRS & - & Götit & Kuru Sıva & Organik: $\approx$ Gum \\
\hline P3a & FT-IR & - & Belirsiz & Kuru Sıva & Organik: $\approx$ protein/yăg \\
\hline P3c & FT-IR & - & Belirsiz & Kuru Sıva & Organik: $\approx$ protein/yăg \\
\hline P4 & FT-IR & - & Belirsiz & Kuru Sıva & $\approx$ akrilik \\
\hline P5a & FT-IR, KRS & - & Karbon & Kuru Sıva & Organik: $\approx$ protein/yăg \\
\hline P5b & FT-IR, KRS & - & Hematit & Kuru Sıva & Belirsiz \\
\hline
\end{tabular}


Yeni yapılan sıva ise, batı duvarının yanı sıra güney ve kuzey duvarlarında da tespit edilen, çimento içeriklidir. Batı, güney ve kuzey duvarlarındaki çimento içerikli sıvaların (S2, S4 ve S5) agrega-bağlayıcı oranları, agrega boyutları ve nitelikleri benzer özelliktedir. Bu sonuç petrografik ve kimyasal analiz sonuçlarıyla da desteklenmektedir. Analizlerde çimento içerikli olduğu sonucuna varılan S2 ve S4 örnekleri ile aynı agrega/bağlayıcı oranlarına sahip S5 örneğinin de çimentolu olduğu düşünülmektedir ${ }^{28}$.

Killi kerpiç harcı ile oluşturulan moloz dolgu harcı (H1) ile kaba sıva (S1b) harcının agrega oranları ve boyutları birbirine oldukça benzemektedir (G. 7 ve G. 8). Buradaki FT-IR spekrumunda zayıf kireç bantlarının görünmesi düşük kireç oranı ile açıklanabilir (G. 10). Ancak diğerinden farklı olarak S1b örneği kaba sıva harcı kıtık içermektedir.

Sıva ve harç örneklerinden yalnızca H2 örneğinde alçı bulunmaktadır. Bu sonuç mihrap çerçevesinin alçı ile yapıldığını göstermektedir (Tablo 6 ve G. 10).

Mihrap ve minber arkasından (özgün dönemler) alınan boya örneklerinde genel olarak doğal mineral kökenli pigmentlerin kullanıldığ 1 ancak yapay olarak elde edilen krom sarısının $\left(\mathrm{PbCrO}_{4}\right)$ da tercih edildiği görülmektedir. Ayrıca boyalar içerisinde daha sonraki araştırmalarda detaylı olarak irdelenmesi gereken polisakkarit (gum), protein/yağ, reçine kaynaklı bağlayıcı maddelerin kullanıldığı ve kalsiyum oksalat $\left(\mathrm{CaC}_{2} \mathrm{O}_{4}\right)$ veya sülfat $\left(\mathrm{SO}_{4}{ }^{2}-\right)$ tuzlarının olabileceği sonucuna varılmıştır $(\mathbf{G} .11$ ve Tablo 10). Böylelikle, çimento içerikli sıvanın üzerinde bulunan P4 örneğinde yakın dönem akrilik boyalarının, P1a örneğinde hayvansal kökenli gomalak reçinesinin, P2b örneğinde polisakkarit kaynaklı bir bağlayıcının, diğer örneklerde ise hem yağ hem de protein içeren ve yumurta olabileceğ i $^{29}$ düşünülen bağlayıcılar kullanılmış olabilir.

\section{Sonuç}

Karabük-Ovacık’ta bulunan Çukur Köyü Camisi'nden alınan harç-sıva, taş ve pigment türü malzemeler üzerinde arkeometrik analizler yapılmıştır. Harç-sıvalardaki agrega bağlayıcı oranları ile bağlayıcılardaki alçı, kireç ve çimento içerikleri hakkında verilere ulaşılmıştır. Petrografik analizlere göre yapıda kullanılan taşlar metakumtaşı olarak tanımlanmıştır. Yapının temelinde kullanılan moloz dolgu harcı killi kerpiç harcı; batı duvarındaki minberin arkasında kalan sıvanın ilk katı kıtık katkılı kil, ikinci katı kıtık katkılı kireç; diğer cephelerdeki sıvalar (güney ve kuzey) çimento içerikli olarak belirlenmiştir. Mihrap sıvasında ise kıtık katkılı kireç sıva kullanılırken, mihrabın dış çerçevesinde alçı harcına rastlanmıştır. Boyalarda, doğal ve yapay kaynaklı pigmentlerin ve farklı türlerde

28 Örnek miktarı az olduğundan FT-IR ve PED-XRF analizi yapılamamıştır.

29 Ralph Mayer, The Artist's Handbook of Materials and Techniques (New York: The Viking Press, 1991), 232-235. 
organik bağlayıcıların (protein, yağ ve reçine) kullanıldığı; yakın dönem çimento esaslı duvarlardaki süslemelerde ise modern boyaların tercih edildiği görülmektedir.

Sonuç olarak, daha detaylı olarak yapılacak analizler ile özellikle boyalarda kullanılan bağlayıcıların ayrıntılı bir karakterizasyonunun sağlanabileceği; ileride yapılacak benzeri araştırmaların ise Osmanlı döneminde kullanılan yapı malzemeleri hakkında literatüre katkı sağlayacağı düşünülmektedir.

Hakem Değerlendirmesi: Dış bağımsız.

Çıkar Çatışması: Yazarlar çıkar çatışması bildirmemiştir.

Finansal Destek: Yazarlar bu çalışma için finansal destek almadığını beyan etmiştir.

Teşekkür: Çalışmada yapılan analizler ile ilgili destekleri için "Kastamonu Üniversitesi Merkezi Araştırma Laboratuvarı Uygulama ve Araştırma Merkezi (MERLAB)” ve “Ankara Üniversitesi Yer Bilimleri Uygulama ve Araştırma Merkezi (YEBİM)”ne teşekkürlerimizi sunarız.

Peer-review: Externally peer-reviewed.

Conflict of Interest: The authors have no conflict of interest to declare.

Grant Support: The authors declared that this study has received no financial support.

Acknowledgement: We would like to thank "Kastamonu University Central Research Laboratory Application and Research Center (MERLAB)" and "Ankara University Earth Sciences Application and Research Center (YEBIM)" for their support regarding the analyzes conducted in the study.

\section{Kaynakça/References}

Akyol, Ali Akın ve Murat Eroğlu. 21. Yüzyılda Türk Sanatı: Meseleler ve Çözüm Önerileri. Kastamonu: Kastamonu Üniversitesi Yayınları, 2018. Erişim 25 Mayıs 2021. https://gstf. kastamonu.edu.tr/index.php/tr/bilgi-sistemleri/haberler-tr/3198-21

Alkan, Nimet, Ergün Çağıran, Hazal Özlem Ersan ve Mustafa Eruş. Restorasyon ve Konservasyon Laboratuvarları. İstanbul: İstanbul Büyükşehir Belediyesi İmar ve Şehircilik Daire Başkanlığı Koruma Uygulama ve Denetim Müdürlüğü (KUDEB) Restorasyon ve Konservasyon Laboratuvarları Yayınları, 2011.

Avan Mimarlık Restorasyon. Çukur Camii Plan Çizimleri, 2016.

Aydın, Murat. "Kalsiyum Alüminat Çimentosu İle Portland Çimentosunun Karşılaştırılması". Yüksek Lisans Tezi, Çukurova Üniversitesi, 2019.

Boynton, Robert, S. Chemistry and Technology of Lime and Limestone. New York: John Wiley \& Sons Inc, 1980.

Büyüksırt, Tuba, Hakan Kuleaşan. "Fourier Dönüşümlü Kizilötesi (FTIR) Spektroskopisi ve G1da Analizlerinde Kullanımı”. Gıda 39 (2014 ): 235-241.

Corso, Gaetano, M. Gelzo, C. Sangers, A. Chambery, A. Di Maro, V. Severino, A. D. Russo, C. Piccioli, P. Arcari. "Polar and Non-polar Organic Binder Characterization in Pompeian Wall Paintings: Comparison to a Simulated Painting Mimicking An "a secco" Technique". Anal Bioanal Chem 402, (2012): 3011-3016.

Database of ATR-FT-IR spectra of various materials. Erişim 11 Eylül 2020. http://lisa.chem.ut.ee/ IR_spectra/

Deniz, Kıymet. "Buzlukdağ (Kırşehir) Alkali Magmatik Kayaçların Jeolojisi, Petrolojisi ve Konfikal Raman Spektrometresi ile İncelenmesi”. Yüksek Lisans Tezi, Ankara Üniversitesi, 2010. 
Derrick, Michele R., Dusan Stulik and James M. Landry. Infrared Spectroscopy in Conservation Science Scientific Tools for Conservation. Los Angeles: The Getty Conservation Institute, 1999.

Güleç, Ahmet. "Süleymaniye Camii Kalemişi Boyalarının Analizleri”. Vakıf Restorasyon Yıllığı 3, (2011):113-122.

Inal, Ali, Aydın Gunes, David J. Pilbeam, Yusuf K. Kadioglu ve Figen Eraslan. "Concentrations of Essential and Nonessential Elements in Shoots and Storage Roots of Carrot Grown in Nacl and $\mathrm{Na}_{2} \mathrm{SO}_{4}$ Salinity". X-Ray Spectrometry 38(1), (2009): 45-51.

Kastamonu Vakıflar Bölge Müdürlügü Arşivi, Çukur Camii Belgeleri.

Kaya, Lütfiye Göktaş ve Şeref Kaya. "Çukur Village Mosque With Its Architectural Properties And Hand Drawn Ornaments”, Uluslararası Sosyal Araştırmalar Dergisi 49 (10), (2017): 200-211.

Kerr, Paul F. Optical Mineralogy. New York: McGraw-Hill, 1977.

Küçükkaya, Ayşe Gülçin. Taşların Bozulma Nedenleri Koruma Yöntemleri. İstanbul: Birsen Yayınevi, 2004.

Mayer, Ralph. The Artist's Handbook of Materials and Techniques. New York: The Viking Press, 1991.

Mora, Paolo, Laura Mora ve Paul Philippot. Conservation of Wall Paintings. London: Butterworths, 1984.

Ndiaye, M., M. Diop ve P. M. Ngom. "Pozzolanic Activity of Acidic and Intermediate Volkanic Tuffs of Mako Areas (Senegal)”. Ed. E Yüzer, H. Ergin ve A. Tuğrul. International Symposium on Industrial Minerals and Building Stones (IMBS'2003), İstanbul: Kelebek ve Grafika Grup, 2003, 517-525.

Pigments Through the Ages. Erişim 01 Ekim 2020. http://www.webexhibits.org/pigments/

Rapp, George. Archaeomineralogy. Berlin: Springer-Verlag, 2002.

Rosi, Francesca, Alessia Daveri, Costanza Miliani, Giovanni Verri, Paolo Benedetti, Francesca Pique, Bruno Brunetti, A Sgamellotti. "Non-invasive Identification of Organic Materials in Wall Paintings by Fiber Optic Reflectance Infrared Spectroscopy: A Statistical Multivariate Approach”. Analytical and bioanalytical chemistry 395. (2009): 2097-2106.

Sarmiento, A., M. Pérez Alonso, M. Olivares, K.Castro, I. Martínez-Arkarazo, L. Fernández, ve J. Madariaga. "Classification and Identification of Organic Binding Media in Artworks by Means of Fourier Transform İnfrared Spectroscopy and Principal Component Analysis". Analytical and Bioanalytical Chemistry 399, (2011): 3601-3611.

Vahur, Signe, Anu Teearu, Pilleriin Peets, Lauri Joosu ve Ivo Leito. “ATR-FT-IR Spectral Collection of Conservation Materials in the Extended Region of 4000-80 cm-1". Anal Bioanal Chem 408, (2016): 3373-3379.

Yazıcıŏlu, Hulusi. Safranbolu-Karabük-Ulus-Eflani, Karabük: Özer Matbaası, 1982.

Yetiş, Ezgin. “Tarihi Duvar Resimlerinde Kullanılan Boya ve Bağlayıcılar”. Ed. C. Ünal ve C. Gürbıyık. Uluslararası XIX. Ortaçağ ve Türk Dönemi Kazıları ve Sanat Tarihi Araştırmaları Sempozyuтu C.2. Ankara: Türk Tarih Kurumu Yayınları, 2019, 507-530.

Yerbilimleri Harita ve Görüntüleyici ve Çizim Editörü. Erişim 25 Mayıs 2018. http://yerbilimleri. mta.gov.tr

Zadrożna, Irmina, Kasia Połeć-Pawlak, Iwona Głuch, Mohamed A. Ackacha, Mirosław Mojski, Janina Witowska-Jarosz ve Maciej Jarosz. "Old Master Paintings- A Fruitful Field of Activity for Analysts: Targets, Methods, Outlook”. Journal of Separation Science 26, (2003): 996-1004.

Zhan, Xiuchun. "Application of Polarized EDXRF in Geochemical Sample Analysis and Comparison with WDXRF”. X-Ray Spectrometry 34(3), (2005): 207-212. 
